\title{
Targeting integrins with RGD-conjugated gold nanoparticles in radiotherapy decreases the invasive activity of breast cancer cells
}

This article was published in the following Dove Press journal:

International Journal of Nanomedicine

14 July 2017

Number of times this article has been viewed

\author{
Ping-Hsiu Wu' \\ Yasuhito Onodera ${ }^{2}$ \\ Yuki Ichikawa ${ }^{3,4}$ \\ Erinn B Rankin ${ }^{5}$ \\ Amato J Giaccia ${ }^{5}$ \\ Yuko Watanabe ${ }^{3}$ \\ Wei Qian ${ }^{4}$ \\ Takayuki Hashimoto' \\ Hiroki Shirato 1,6,7 \\ Jin-Min $\mathrm{Nam}^{1,6,7}$
}

'Department of Radiation Medicine, ${ }^{2}$ Department of Molecular Biology, Graduate School of Medicine, Hokkaido University, Hokkaido, ${ }^{3}$ Innovation Center, Aisin Seiki Co., Ltd., Aichi, Japan; ${ }^{4}$ IMRA America, Inc., Ann Arbor, MI, ${ }^{5}$ Department of Radiation Oncology, Division of Radiation and Cancer Biology, Stanford University Medical Center, Stanford, CA, USA; ${ }^{6}$ Research Center for Cooperative Projects, Graduate School of Medicine, ${ }^{7}$ Global Station for Quantum Medical Science and Engineering, Global Institution for Collaborative Research and Education, Hokkaido University, Hokkaido, Japan

Correspondence: Jin-Min Nam Department of Radiation Medicine, Graduate School of Medicine, Hokkaido University, North-15, West-7, Kita-ku, Sapporo, Hokkaido 060-8638, Japan

Tel +8I II 7065076

Fax +8I I| 7067005

Email jinmini@med.hokudai.ac.jp
Abstract: Gold nanoparticles (AuNPs) have recently attracted attention as clinical agents for enhancing the effect of radiotherapy in various cancers. Although radiotherapy is a standard treatment for cancers, invasive recurrence and metastasis are significant clinical problems. Several studies have suggested that radiation promotes the invasion of cancer cells by activating molecular mechanisms involving integrin and fibronectin (FN). In this study, polyethylene-glycolylated AuNPs (P-AuNPs) were conjugated with Arg-Gly-Asp (RGD) peptides (RGD/P-AuNPs) to target cancer cells expressing RGD-binding integrins such as $\alpha 5$ - and $\alpha \mathrm{v}$-integrins. RGD/PAuNPs were internalized more efficiently and colocalized with integrins in the late endosomes and lysosomes of MDA-MB-231 cells. A combination of RGD/P-AuNPs and radiation reduced cancer cell viability and increased DNA damage compared to radiation alone in MDA-MB-231 cells. Moreover, the invasive activity of breast cancer cell lines after radiation treatment was significantly inhibited in the presence of RGD/P-AuNPs. Microarray analyses revealed that the expression of FN in irradiated cells was suppressed by combined use of RGD/P-AuNPs. Reduction of FN and downstream signaling may be involved in suppressing radiation-induced invasive activity by RGD/P-AuNPs. Our study suggests that RGD/P-AuNPs can target integrinoverexpressing cancer cells to improve radiation therapy by suppressing invasive activity in addition to sensitization. Thus, these findings provide a possible clinical strategy for using AuNPs to treat invasive breast cancer following radiotherapy.

Keywords: gold nanoparticles, radiotherapy, breast cancer, invasion, integrin, fibronectin

\section{Introduction}

In recent years, gold nanoparticles (AuNPs) have been widely studied for drug delivery, ${ }^{1}$ imaging, ${ }^{2}$ and cancer diagnostics. ${ }^{3,4}$ As a high atomic number $(Z)$ material, AuNPs can serve as sensitizers to enhance the effects of ionizing radiation (IR) through the photoelectric effect. ${ }^{5}$ In recent studies, the size, shape and surface properties of nanoparticles were shown to improve the efficacy of tumor targeting ${ }^{6,7}$ and enhance the effect of cancer therapy. ${ }^{8,9}$ AuNPs may increase the effects of radiation by producing secondary electrons and reactive oxygen species (ROS), increasing double-strand DNA breaks. ${ }^{10}$ Recently, radiosensitization using AuNPs has achieved high specificity and efficiency in breast cancer cells by targeting specific molecules. ${ }^{11}$ Although surface modification of nanoparticles enables high targeting specificity, Gilles et $\mathrm{al}^{12}$ suggested that it may decrease hydroxyl radical production, in turn reducing DNA damages. Therefore, it is important to optimize size and surface modification in the production of AuNPs. In addition, the detailed molecular mechanisms of AuNPs-mediated radiosensitization must be examined to maximize its efficacy in future clinical application. 
Radiation therapy is a standard treatment for local breast cancer. Adjuvant radiotherapy after breast conserving surgery may reduce the 10-year risk of first recurrence from 35.0\% to $19.3 \%$ and 15 -year risk from $25.2 \%$ to $21.4 \% .{ }^{13}$ However, high-dose and large-field radiotherapy can cause side effects such as radiation dermatitis, lymphedema, lung toxicity, long-term cardiac toxicity and thyroid toxicity. ${ }^{14,15}$ Although lower doses are utilized for clinical treatment, $19.3 \%$ of breast cancer patients develop invasive recurrent disease following radiotherapy. ${ }^{15}$ Additionally, radiation was reported to enhance the invasive potential of some cancer cells. ${ }^{16} \mathrm{We}$ previously showed that $\alpha 5 \beta 1$-integrin and fibronectin (FN) signaling is upregulated and drives the invasive potential of a subset of breast cancer cells following IR. ${ }^{17}$

Integrins are heterodimeric cell surface receptors that mediate the adhesion of cells to the extracellular matrix. ${ }^{18}$ The arginine (R)-glycine (G)-aspartic acid (D) (RGD) sequence is included in FN and associates with several types of integrins, such as $\alpha 5 \beta 1-, \alpha v \beta 3$ - and $\alpha v \beta 5$-integrins. ${ }^{18}$ There are 24 integrin heterodimers, and several types are highly expressed in various tumor types including breast cancer. ${ }^{19}$ Signaling mediated by integrins is essential for cancer invasion, metastasis and radioresistance of breast cancer cells. ${ }^{20,21}$ Integrins bound to the RGD sequence of FN internalize into cells together with FN by endocytosis. Endocytosis and recycling of integrins play essential roles in cancer cell migration and invasion. ${ }^{22-25}$

In this study, we conjugated (RGD), peptides on polyethylene glycolylated (PEGylated) AuNPs (P-AuNPs) to enable binding to integrins and internalization into cancer cells via endocytosis. We evaluated whether targeting integrins with RGD-conjugated P-AuNPs (RGD/P-AuNPs) could enhance radiation effects in cancer cells. We found that RGD/P-AuNPs internalized and colocalized with integrins, as well as accumulated in late endosomes and lysosomes in breast cancer cells. To investigate the therapeutic potential of RGD/P-AuNPs, we measured cancer cell survival and invasive activity after combined treatment with AuNPs and IR. Our data suggest that RGD/P-AuNPs improve radiation effects by suppressing the invasive activity of breast cancer after radiation treatment.

\section{Materials and methods AuNPs}

i-colloid ${ }^{\mathrm{TM}} \mathrm{Au} 15 \mathrm{~nm}$ (optical density 1 [OD1]) and $20 \mathrm{~nm}$ (OD1) from IMRA America, Inc., were used to take advantage of its novel surface properties allowing sequential surface modification. ${ }^{26-28}$ Methoxy-PEG-thiol, MW 5k
(methoxy-PEG-thiol, MW 5,345, substitution purity: $>90 \%$, abbreviated as "mPEG-SH5k"), was purchased from Creative PEGWorks (Chapel Hill, NC, USA). Fluorescein isothiocyanate-PEG-thiol, MW 5k (FITC-PEG-SH, substitution purity: $>80 \%$, "FITC-PEG-SH5k"), was purchased from Nanocs, Inc (New York, NY, USA). Cysteine-modified (RGD), peptide (MW: 1,845.98, purity: $>95 \%$, abbreviated as "RGD peptide") with amino acid sequence RGDRGDRGDRGDPGC was purchased from RS synthesis, LLC (Louisville, KY, USA). Methoxy-PEG-SH5k, FITC-PEG-SH5k and RGD peptide were in powder form and dissolved in deionized (DI) water having an electric conductivity of $<0.1 \mu \mathrm{S} / \mathrm{cm}$ without further purification. All solutions were freshly made as needed and used within 12 h. Dynamic light scattering (DLS) measurement with Zetasizer Nano ZS90 (Malvern Instruments, Malvern, Worcestershire, UK) was employed to measure an increase in hydrodynamic diameter of AuNPs with surface modification. UV-2700 UV-Vis Spectrophotometer (Shimadzu Corporation, Kyoto, Japan) was used for optical density (OD) or absorbance measurement of the colloidal suspension.

\section{Synthesis of PEGylated AuNPs and RGD peptide/mPEG-SH5k-AuNPs}

i-colloid $\mathrm{Au} 15 \mathrm{~nm}$ or $20 \mathrm{~nm}$ was mixed with a solution of mPEG-SH5k or FITC-PEG-SH5k having a concentration to achieve a defined ratio of PEG to AuNPs and was kept undisturbed for longer than $12 \mathrm{~h}$. After the reaction, two runs of centrifugal purification $(12,000 \times g, 15 \mathrm{~min}$ for $\mathrm{Au}$ $15 \mathrm{~nm} ; 5,000 \times g, 20 \mathrm{~min}$ for $\mathrm{Au} 20 \mathrm{~nm}$ ) were carried out. Final OD was adjusted to $\sim 30$ by adding DI water to the pellet after removing the supernatant. Partially PEGylated AuNPs (P-AuNPs) were further conjugated with RGD peptides (RGD/P-AuNPs). P-AuNPs (OD30) and 0.2 M borate buffer ( $\mathrm{pH}$ 8.2) were mixed with RGD peptide solution to achieve a ratio of RGD to AuNPs of 1,200 in $4 \mathrm{mM}$ borate buffer ( $\mathrm{pH}$ 8.2). The solution was kept undisturbed for longer than $24 \mathrm{~h}$. After the reaction, two runs of centrifugal purification $(12,000 \times g, 15 \mathrm{~min}$ for Au $15 \mathrm{~nm}, 5,000 \times g ; 20 \mathrm{~min}$ for $\mathrm{Au}$ $20 \mathrm{~nm}$ ) were carried out in $4 \mathrm{mM}$ borate buffer ( $\mathrm{pH} \mathrm{8.2)}$. Finally, OD was adjusted to $\sim 30$ by adding $4 \mathrm{mM}$ borate buffer ( $\mathrm{pH}$ 8.2) to the pellet after discarding the supernatant.

\section{Characterization of AuNPs}

The size distribution of unconjugated AuNPs was analyzed by the method of differential centrifugal sedimentation using CPS Disc Centrifuge instrument (model DC24000 UHR; CPS Instruments Inc., Prairieville, LA, USA). Hydrodynamic diameter and zeta potential of AuNPs during the 
fabrication of RGD/P-AuNPs were obtained from DLS measurements using a Zetasizer Nano ZS90 (Malvern Instruments). Transmission electron microscope (TEM) analysis was performed by using JEOL JEM-2100F transmission electron microscope (JEOL Ltd., Tokyo, Japan).

\section{Cell culture and AuNP treatment}

Human breast cancer cell lines, MDA-MB-231, Hs578T and SK-BR-3, were obtained from the American Type Culture Collection (ATCC, Manassas, VA, USA) and cultured in Dulbecco's Modified Eagle's Medium (DMEM; SigmaAldrich, St Louis, MO, USA) supplemented with 10\% fetal bovine serum (FBS; HyClone, GE Healthcare Life Sciences, Logan, UT, USA). Prior to AuNP treatment, cells were seeded into $35 \mathrm{~mm}$ dish and incubated for $24 \mathrm{~h}$ and then replaced with medium containing $0.3 \mathrm{nM}$ (1:90 dilution) or $1 \mathrm{nM}$ (1:30 dilution) of $20 \mathrm{~nm}$ AuNPs.

\section{Irradiation}

Cells were irradiated with $130 \mathrm{kV}$ X-rays using Faxitron CellRad X-ray generator (Faxitron, Tucson, AZ, USA) after incubation of AuNPs for $48 \mathrm{~h}$.

\section{Lysis and Western blotting}

Cells were lysed in $1 \%$ radioimmunoprecipitation assay (RIPA) buffer (1\% NP-40, $150 \mathrm{mM} \mathrm{NaCl}, 50 \mathrm{mM}$ Tris-HCl [pH 7.4], 5 mM ethylenediaminetetraacetic acid [EDTA], 1\% sodium deoxycholate, $0.1 \%$ sodium dodecyl sulfate [SDS], $1 \mathrm{mM} \mathrm{Na}_{3} \mathrm{VO}_{4}, 1 \mathrm{mM} \mathrm{NaF}$ and protease inhibitor cocktail; Merck Millipore, Darmstadt, Germany). Proteins were transferred onto polyvinylidene fluoride (PVDF) membrane (Merck Millipore). The membranes were blocked with Odyssey ${ }^{\circledR}$ blocking buffer (LI-CORE Biosciences, Lincoln, NE, USA) and were probed with primary antibodies. After washing with Tris-buffered saline Tween-20 (TBST; $25 \mathrm{mM}$ [pH 7.4], $120 \mathrm{mM} \mathrm{NaCl}, 3 \mathrm{mM} \mathrm{KCl}$ and 0.1\% Tween-20), membranes were incubated with secondary antibody for $1 \mathrm{~h}$ at room temperature and then washed with TBST. The signals were detected with Odyssey CLx Imager (LICORE Biosciences).

\section{Antibodies}

The following primary antibodies were used for immunoblotting: anti- $\alpha 5$-integrin (Merck Millipore), anti- $\alpha v$-integrin (Abcam, Cambridge, UK), anti- $\beta 1$-integrin (BD Transduction Laboratories, San Jose, CA, USA), anti- $\beta 3$-integrin (Merck Millipore), anti- $\beta 5$-integrin (Abcam), anti-pERK (Cell Signaling Technology, Danvers, MA, USA), anti-ERK
(Cell Signaling Technology), anti-LAMP1 (Cell Signaling Technology) and anti- $\beta$-actin (Sigma-Aldrich). The following primary antibodies were used for immunofluorescence staining: anti- $\alpha 5$-integrin (Cell Signaling Technology), anti- $\alpha$ v-integrin (Cell Signaling Technology), anti-LAMP1 (Cell Signaling Technology), anti-EEA1 (Cell Signaling Technology), anti-Rab5 (Cell Signaling Technology), antiRab7 (Cell Signaling Technology), anti-Rab9 (Cell Signaling Technology) and anti- $\gamma$-H2AX (Merck Millipore).

\section{Cell viability assay}

Cell viability and cytotoxicity were examined by the Cell Counting Kit-8 (CCK-8; Dojindo, Kumamoto, Japan) and cell counting. Cells were cultured in 96-well plates and treated with P-AuNPs or RGD/P-AuNPs for 12-48 h and then incubated with CCK-8 solution. For radiosensitivity, cells treated with P-AuNPs or RGD/P-AuNPs received IR $48 \mathrm{~h}$ later and then measured the cell viability with cell counting or CCK-8 solution. The optical density at $450 \mathrm{~nm}$ was determined using Multiskan ${ }^{\mathrm{TM}}$ GO Microplate Spectrophotometer (Thermo Fisher Scientific, Waltham, MA, USA) to measure cell viability.

\section{Immunostaining and image acquisition}

Cells were fixed in 4\% paraformaldehyde and permeabilized with $0.2 \%$ Triton X-100/phosphate-buffered saline (PBS), and then incubated with primary antibodies and coupled with Alexa Fluor secondary antibody. Images were acquired by a Leica True Confocal Scanning (TCS) SP8 microscope system (Leica Microsystems, Wetzlar, Germany) or Fluorescence Microscope BZ-9000 (Keyence, Osaka, Japan). Colocalization analysis with endosome markers was performed with Coloc 2, Fiji's plugin of ImageJ.$^{29}$ For DNA damage assessment, cells incubated with AuNPs were fixed and stained with anti- $\gamma$-H2AX $12 \mathrm{~h}$ after IR. The number of $\gamma$-H2AX foci per nucleus was counted in ImageJ. At least 50 nuclei were analyzed in each independent experiment.

\section{Matrigel invasion assay}

The invasion assay was performed using Biocoat ${ }^{\mathrm{TM}}$ Matrigel $^{\circledR}$ Invasion Chambers (Corning, NY, USA) as described previously. ${ }^{30,31}$ In brief, $10^{5}$ of MDA-MB-231 or $10^{4}$ of Hs $578 \mathrm{~T}$ cells were seeded on to the upper wells of chambers in the absence of serum, and lower wells were filled with culture medium. After $8 \mathrm{~h}$ for MDA-MB-231 cells and $5 \mathrm{~h}$ for Hs578T cells, the cells that migrated out on to the lower surface of the membranes were fixed with $4 \%$ paraformaldehyde. The number of cells was scored by staining with $1 \%$ crystal violet. 


\section{Microarray analysis}

Total cellular RNA was isolated by NucleoSpin ${ }^{\circledR}$ RNA (MACHEREY-NAGEL, Düren, Germany). For the microarray analysis, high sensitive $3 \mathrm{D}-\mathrm{Gene}^{\circledR}$ Human oligo chip $25 \mathrm{k}$ ver 2.10 (Toray Industries) was used. The data were normalized and analyzed by Toray Industries.

\section{Quantitative reverse transcription polymerase chain reaction (RT-PCR)}

Complementary DNA (cDNA) was synthesized from total RNA by SuperScript ${ }^{\text {TM }}$ First-Strand Synthesis System (Thermo Fisher Scientific) using random primers. Quantitative real-time PCR was performed with the LightCycler $^{\circledR}$ nano system (Hoffman-La Roche Ltd., Basel, Switzerland) using FastStart Essential DNA Green Master kit (Hoffman-La Roche Ltd.). The following primers were used to amplify FN and 18S rRNA: total FN, 5'-CCAAGCT CAAGTGGTCCTGT-3' (forward) and 5'-CACTTCTTGG TGGCCGTACT-3' (reverse); 18S rRNA, 5'-TCGGAAC TGAGGCCATGATT-3' (forward) and 5'-CCTCCG ACTTTCGTTCTTGATT-3' (reverse).

\section{Statistical analysis}

Graphs are expressed as mean \pm standard error (SE). Data were analyzed by Student's $t$-test. Significant differences are indicated by $* P<0.05, * * P<0.01,{ }^{* * *} P<0.001$ and $\mathrm{ns}$ for not significant.

\section{Results}

\section{Fabrication and characterization of P-AuNPs and RGD/P-AuNPs}

Integrins, such as $\alpha 5 \beta 1-, \alpha v \beta 3$ - and $\alpha v \beta 5$-integrins, can associate with FN through the RGD sequence. ${ }^{32}$ To target integrins with AuNPs and increase cellular uptake of AuNPs through the endocytosis of integrins, we conjugated RGD peptide to P-AuNPs (15 nm or $20 \mathrm{~nm}$ diameter). i-colloid $\mathrm{Au}$ was partially PEGylated (abbreviated as "P-AuNPs") and subsequently conjugated with cysteine-modified (RGD) ${ }_{4}$ peptides (abbreviated as "RGD/P-AuNPs") (Figure 1A). ${ }^{26,27}$ A layer of PEG on the surface of AuNPs enhances stability under physiological conditions by providing a steric barrier as described previously. ${ }^{26}$ Dark-field TEM images of synthesized AuNPs are shown in Figure 1B. TEM images of P-AuNPs and RGD/P-AuNPs are shown in Figure S1. The size distribution of AuNPs was analyzed by differential centrifugal sedimentation (Figure 1C). The peak size was $19.3 \mathrm{~nm}$ in the weight size distribution graph (weight of nanoparticles plotted against diameter), and polydispersity index (PDI) was 1.17 defined as the ratio between weight average diameter $(\mathrm{Dw})$ and number average diameter $(\mathrm{Dn})$. To prepare a perfectly uniform sample consisting of exactly one size, Dw and Dn should be the same value and PDI should be 1.0 .

The hydrodynamic diameter (Figure 1D, left) and zeta potential (Figure 1D, right) of AuNPs were obtained by DLS measurements during the fabrication of RGD/P-AuNPs. The results showed that the diameter of AuNPs increased and the absolute zeta potential of AuNPs decreased along with the sequential conjugation of PEG molecules and RGD peptides, confirming the result of AuNPs binding with PEG molecules and RGD peptides on to the surface. Figure 1E shows the hydrodynamic diameters of the P-AuNPs (input molar ratio of PEG to AuNP, PEG/AuNP, used was 400:1) conjugated with different amounts of RGD peptides. The increase in hydrodynamic size was plotted against the increased amounts of RGD peptides added to the P-AuNPs. The results showed that the diameter of the AuNPs first increased with an increasing molar ratio of RGD peptides to P-AuNPs (RGD/P-AuNPs) from 0 to 1,000 and then plateaued for RGD peptides $>1,000$, representing saturation of RGD peptides on the surface of P-AuNPs. Based on this result, $\sim 1,000$ RGD peptides were conjugated to each P-AuNP with an initial input molar ratio of RGD peptides to one P-AuNP of 1,200 in the fabrication of RGD/P-AuNPs.

\section{Internalization and colocalization of RGD/P-AuNPs with integrins in breast cancer cells}

Integrins exhibit diverse expression patterns in several types of cancer cells. ${ }^{19} \mathrm{We}$ previously showed that $\alpha 5 \beta 1$-integrin is upregulated in highly invasive breast cancer cells in threedimensional laminin-rich extracellular matrix cultures. ${ }^{33}$ To determine which breast cancer cell lines can be targeted by RGD/P-AuNPs, we compared the protein expression level of the RGD receptors, $\alpha 5 \beta 1$-, $\alpha v \beta 5$ - and $\alpha v \beta 3$-integrins, in several breast cancer cell lines. We found that the expression of $\alpha 5$ - and $\alpha v$-integrin heterodimers was significantly increased in the highly invasive breast cancer cell lines MDAMB-231 and Hs578T compared to in the minimally invasive breast cancer cell line SK-BR-3 (Figure 2A). We confirmed that RGD/P-AuNPs were internalized into breast cancer cells and accumulated significantly compared to P-AuNPs in MDA-MB-231 and Hs578T cells (Figure 2B). In contrast, SK-BR-3 cells did not take up RGD/P-AuNPs as efficiently as invasive cell lines (Figure 2B). These results indicate that 
A

P-AuNPs

RGD/P-AuNPs

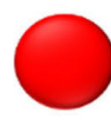

i-colloid

$\mathrm{Au}$

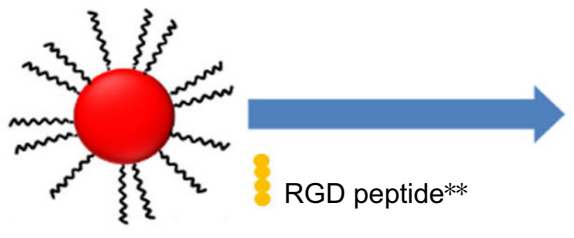

PEGylated

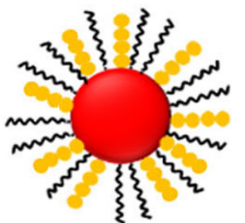

*PEG: $\mathrm{mPEG}-\mathrm{SH}(\mathrm{MW} \sim 5 \mathrm{k})$ or FITC-PEG-SH(MW 5k)

**Amino acid sequence: RGDRGDRGDRGDPGC

B
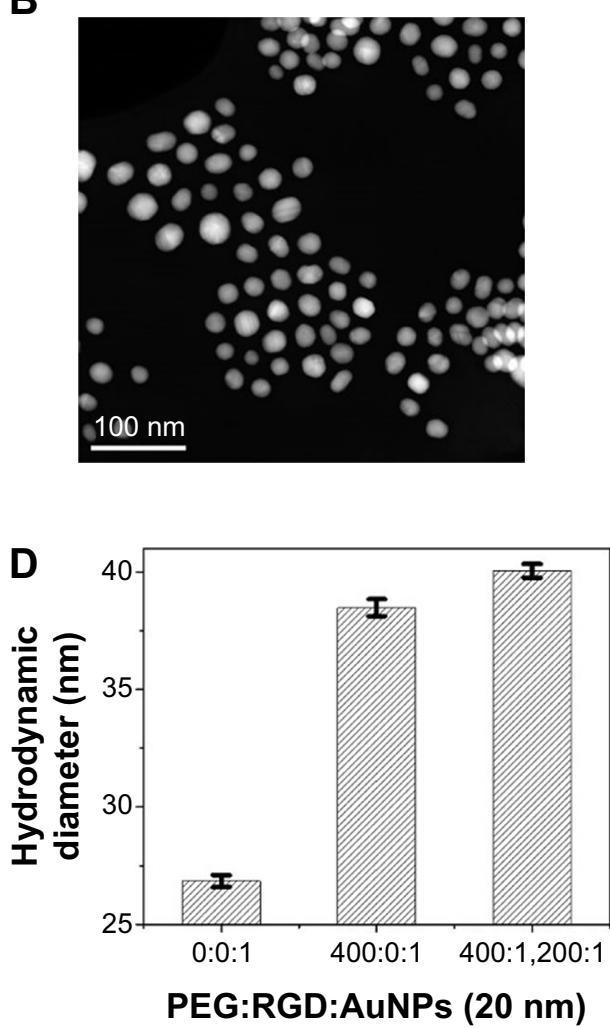

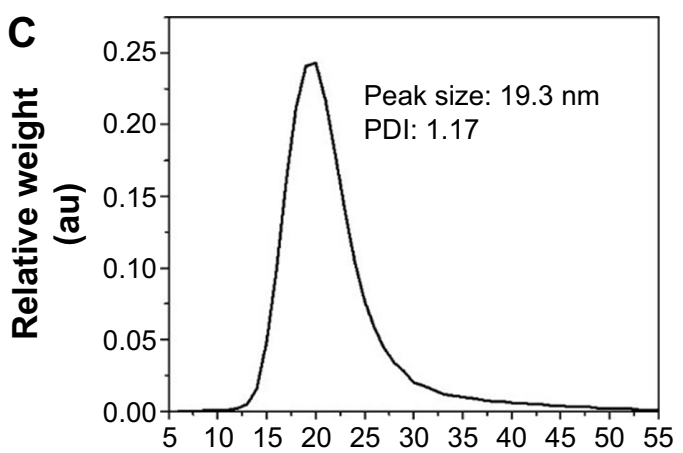

Nanoparticle diameter (nm)

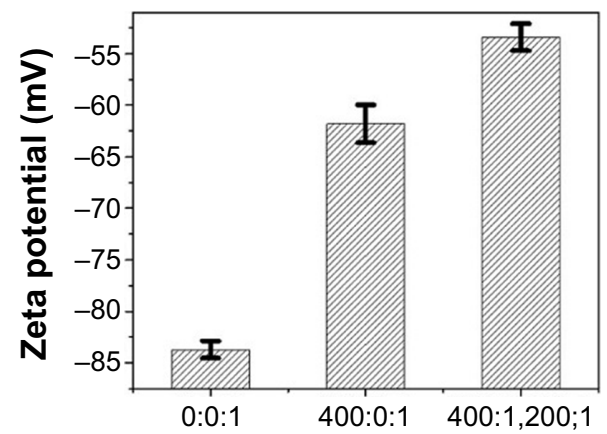

PEG:RGD:AuNPs (20 nm)

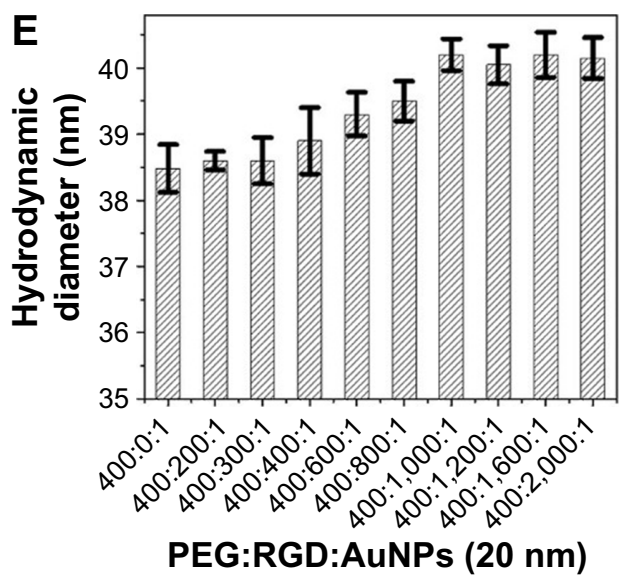

Figure I Fabrication and characterization of RGD/P-AuNPs.

Notes: (A) Schematic diagram of RGD/P-AuNPs. i-colloid ${ }^{T M}$ Au was partially conjugated with PEG (P-AuNPs) and further conjugated with RGD peptides (RGD/P-AuNPs). (B) Dark-field TEM image of synthesized AuNPs. (C) Size distribution of AuNPs and PDI of AuNPs measured by differential centrifugal sedimentation. (D) Hydrodynamic diameter and zeta potential of AuNPs during the fabrication of RGD/P-AuNPs obtained from DLS measurements. (E) Hydrodynamic diameters of P-AuNPs conjugated with different amounts of RGD peptides.

Abbreviations: RGD/P-AuNP, polyethylene-glycolylated gold nanoparticle (P-AuNP) conjugated with Arg-Gly-Asp (RGD) peptides; PEG, polyethylene glycol; TEM, transmission electron microscopy; PDI, polydispersity index; DLS, dynamic light scattering. 
A

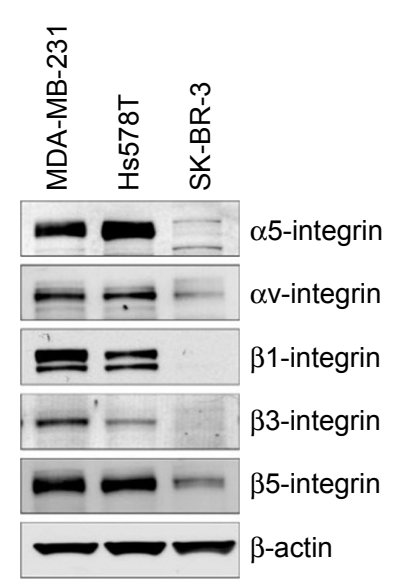

B

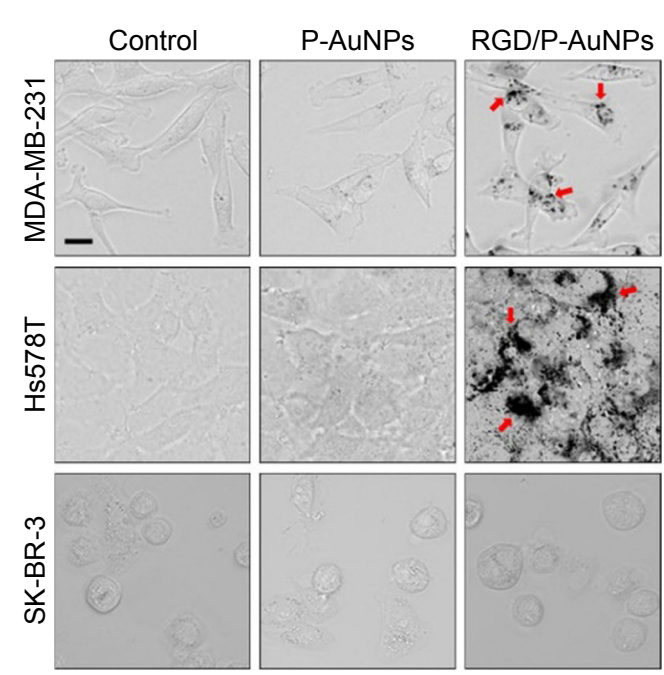

C

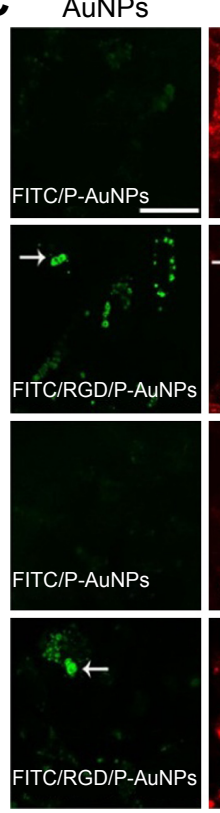

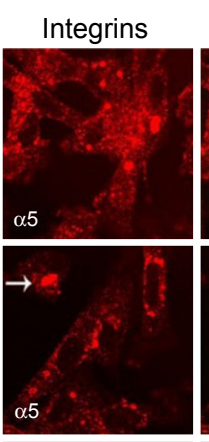
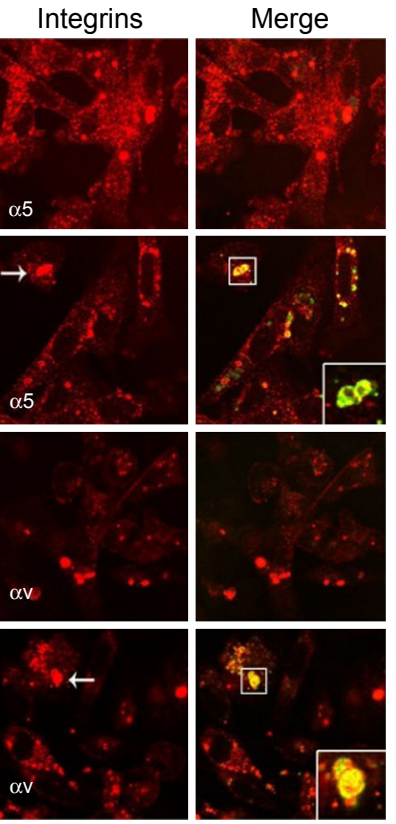

Figure 2 Internalization and colocalization of RGD/P-AuNPs with integrins in breast cancer cells.

Notes: (A) Protein expression of RGD receptors ( $\alpha 5 \beta \mathrm{I}-, \alpha v \beta 5$ - and $\alpha v \beta 3$-integrins) in breast cancer cell lines. Total cell lysates were subjected to Western blotting using the indicated antibodies. (B) Phase-contrast microscopic images of MDA-MB-23I, Hs578T and SK-BR-3 cells cultured with or without AuNPs. Bar, $20 \mu$ m. (C) Confocal immunofluorescence images show localization of FITC-conjugated AuNPs (green) and integrins (red) in cells. MDA-MB-23I cells were cultured with FITC-conjugated AuNPs, and then integrins were labeled with an anti- $\alpha 5$-integrin or $\alpha \mathrm{v}$-integrin antibody coupled to Alexa 568-labeled anti-mouse IgG antibody. White arrows: colocalized FITC/ RGD/P-AuNPs or integrins. Bar, $25 \mu \mathrm{m}$.

Abbreviations: RGD/P-AuNP, polyethylene-glycolylated gold nanoparticle (P-AuNP) conjugated with Arg-Gly-Asp (RGD) peptides; FITC, fluorescein isothiocyanate; IgG, Immunoglobulin G.

the RGD/P-AuNPs can specifically target invasive breast cancer cells with RGD-binding integrins.

We also generated RGD/P-AuNPs using different sizes of i-colloid $\mathrm{Au}$ and confirmed their internalization in invasive breast cancer cell lines (Figure S2A). The effect of AuNP size has been reported previously. ${ }^{34} \mathrm{Chithrani}$ et a $\mathrm{l}^{34}$ showed that AuNPs, $50 \mathrm{~nm}$ in diameter, were most effectively internalized compared to AuNPs 14 and $74 \mathrm{~nm}$ in diameter. In our study, we used $20 \mathrm{~nm}$ i-colloid $\mathrm{Au}$ with the diameter increased to $\sim 40 \mathrm{~nm}$ after PEGylation (Figure S2B).

To determine the localization of RGD/P-AuNPs in cells by fluorescence microscopy, we generated fluorescent RGD/ P-AuNPs using FITC-PEG-SH5k instead of mPEG-SH5k (FITC/RGD/P-AuNPs). Immunofluorescent images obtained by confocal microscopy showed that FITC/RGD/P-AuNPs were colocalized with $\alpha 5$ - or $\alpha$-integrins in endosomal structures in MDA-MB-231 cells (Figure 2C).

\section{Trafficking of RGD/P-AuNPs by integrins to late endosomes and lysosomes in MDA-MB-23I}

To further evaluate the localization of RGD/P-AuNPs, protein markers of different endosomes and lysosomes were immunostained after uptake of FITC/RGD/P-AuNPs (Figure 3A). Rab5 and its effector, early endosome antigen 1 (EEA1), are localized to early endosomes. ${ }^{35,36} \mathrm{Rab} 7$ is a marker of late endosomes and associates with the RIPL effector protein to control membrane trafficking from early to late endosomes and lysosomes. ${ }^{37}$ Rab9 functions in the transport of mannose 6-phosphate receptors between late endosomes and the trans-Golgi network. ${ }^{38} \mathrm{We}$ analyzed the colocalization of FITC/RGD/P-AuNPs and the endosome markers by determining the Pearson product-moment correlation coefficient using software Coloc 2, the Fiji's plugin of ImageJ. FITC/RGD/P-AuNPs were significantly colocalized with Rab7 compared to other markers (Figure 3A and B). There were no significant differences between 1 day and 3 days of incubation of FITC/RGD/P-AuNPs (Figure 3B). These data suggest that RGD/P-AuNPs are internalized by binding to integrins and trafficked to late endosomes in a similar manner to FN. Integrin-bound RGD/P-AuNPs also localized to lysosomes, as FN and integrins were trafficked to lysosomes via late endosomes after ligand-receptor interactions. ${ }^{22}$ Confocal microscopy showed that FITC/RGD/P-AuNPs colocalized with lysosomal-associated membrane protein 1 (LAMP1), a glycoprotein primarily across lysosomal membranes that 


\section{A FITC/RGD/P-AuNPs}
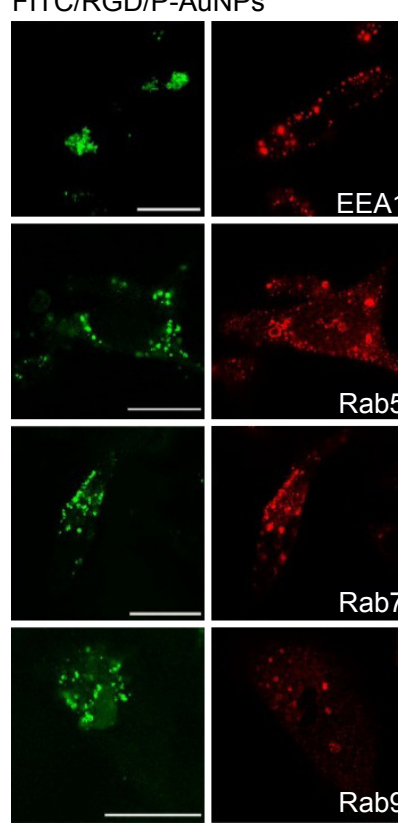

Rab5

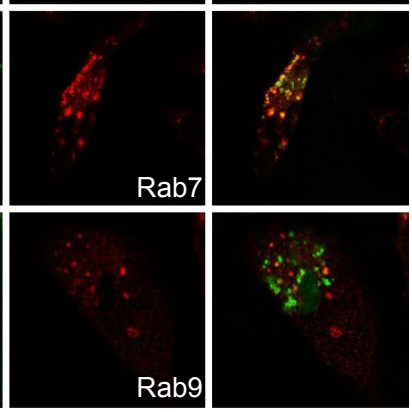

C
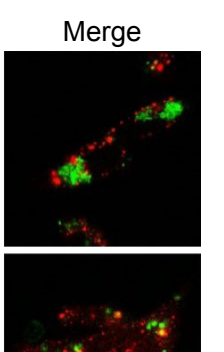

B

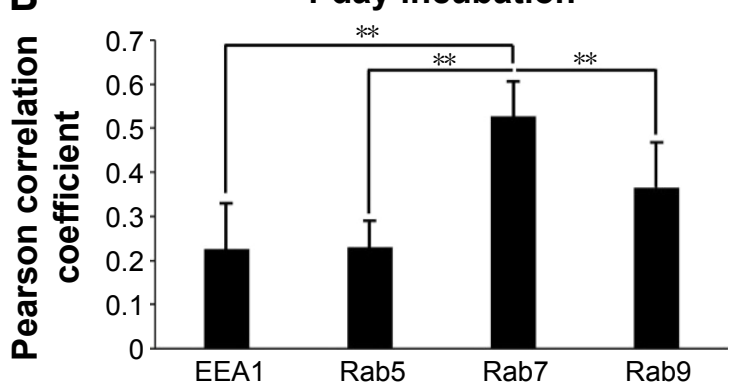

\section{3 days incubation}

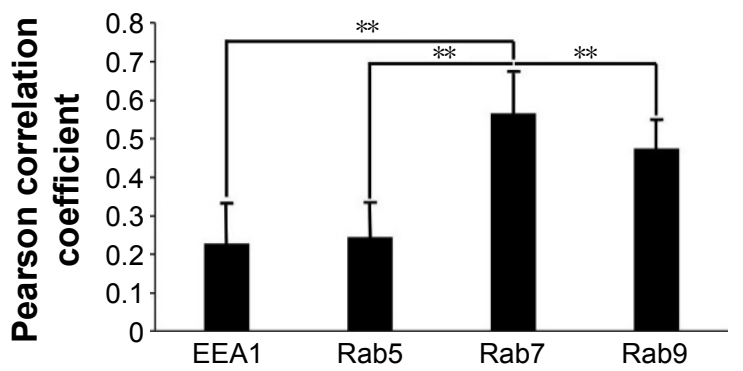

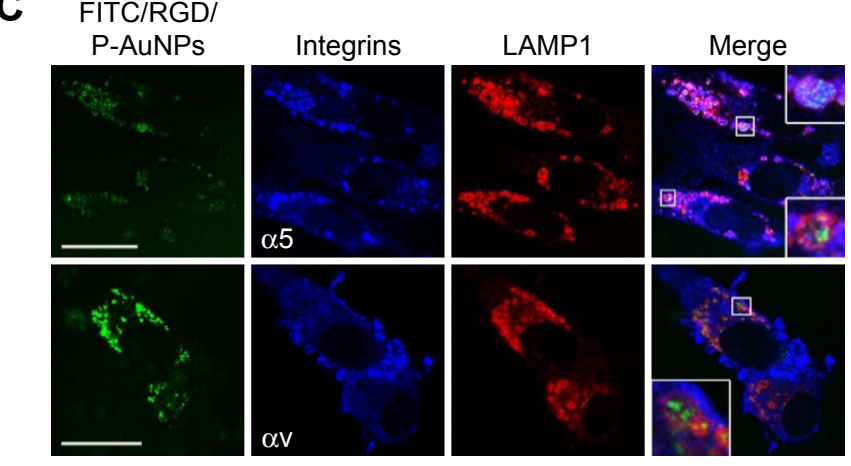

Figure 3 Colocalization of RGD/P-AuNPs with protein markers of early/late endosomes and lysosomes in MDA-MB-23I.

Notes: (A) Confocal immunofluorescence images show localization of FITC-conjugated RGD/P-AuNPs (FITC/RGD/P-AuNPs) (green) and protein markers of endosome/ lysosome (red) in cells. MDA-MB-23I cells were cultured with FITC/RGD/P-AuNPs, and then markers of early endosomes (EEAI/Rab5) and late endosomes (Rab7/Rab9) were labeled with antibodies. Bar, $25 \mu \mathrm{m}$. (B) Colocalization analysis of FITC/RGD/P-AuNPs and proteins of endosome were quantified by Pearson's correlation coefficient using ImageJ software. RGD/P-AuNPs were incubated with MDA-MB-23I cells for I day or 3 days. Columns, mean $(n>I 0)$, bars, SD, $* * P<0.0$ I. (C) Immunofluorescence images of FITC/RGD/P-AuNPs (green), integrins (blue) and LAMPI (red). Integrins were labeled with an anti- $\alpha 5$-integrin or $\alpha \mathrm{v}$-integrin antibody coupled to an Alexa 647labeled anti-mouse lgG antibody. LAMPI was labeled with anti-LAMPI rabbit monoclonal antibody coupled to an Alexa 567-labeled anti-rabbit IgG antibody, which served as a marker of lysosomes. Bar, $25 \mu \mathrm{m}$.

Abbreviations: RGD/P-AuNP, polyethylene-glycolylated gold nanoparticle (P-AuNP) conjugated with Arg-Gly-Asp (RGD) peptides; FITC, fluorescein isothiocyanate; EEAI, early endosome antigen I; SD, standard deviation; LAMPI, lysosomal-associated membrane protein I; IgG, Immunoglobulin G.

is commonly used as a marker of lysosomes (Figure 3C). These data suggest that RGD/P-AuNPs are internalized by binding to integrins and trafficked to late endosomes and lysosomes.

\section{Cytotoxicity and radiosensitization of RGD/P-AuNPs in MDA-MB-23 I cells}

Previous studies demonstrated that AuNPs can enhance the efficacy of radiation to reduce cell viability. ${ }^{11}$ To compare the cytotoxicity and radiosensitization of P-AuNPs and RGD/PAuNPs, we measured cell viability with or without IR.
Individually, P-AuNPs and RGD/P-AuNPs did not show significant cytotoxicity in MDA-MB-231 cells after $12 \mathrm{~h}$, $24 \mathrm{~h}$ and $48 \mathrm{~h}$ of incubation (Figure 4A). Importantly, the combination of 4 Gy IR and RGD/P-AuNP treatments significantly reduced cell viability compared with IR alone in MDA-MB-231 cells (Figure 4B and C). In contrast, the treatment was not effective in the SK-BR-3 cell line, which expresses low levels of integrins and exhibits low cellular uptake of RGD/P-AuNPs (Figure S3). To assess DNA damage, MDA-MB-231 cells after AuNP and/or IR treatment were fixed and stained with $\gamma-\mathrm{H} 2 \mathrm{AX}$, a marker of DNA 

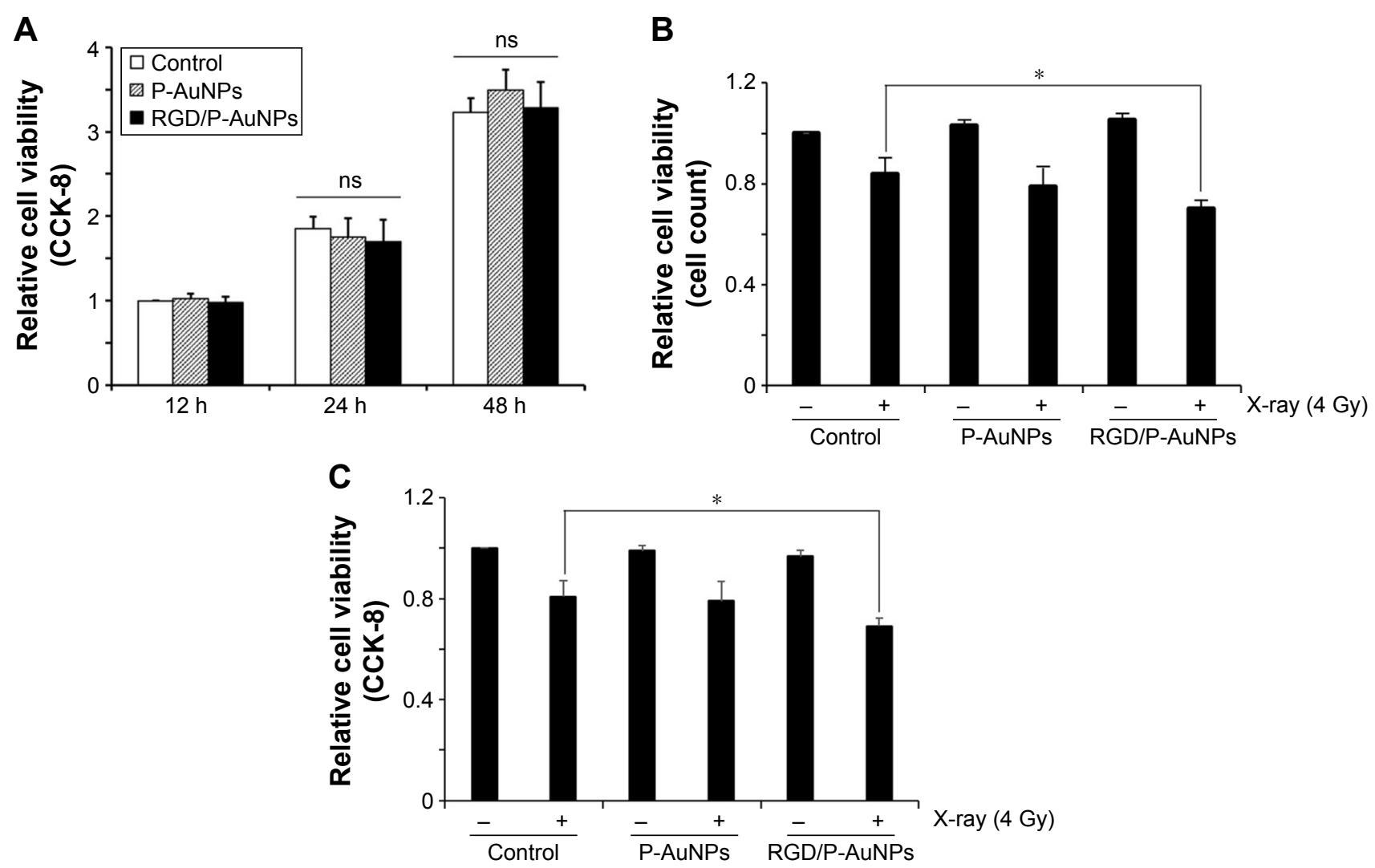

Figure 4 Cytotoxicity and radiosensitivity of RGD/P-AuNPs in cells.

Notes: (A) Cytotoxicity of AuNPs in MDA-MB-23I cells was determined by CCK-8. Absorbance at $450 \mathrm{~nm}$ was measured using a microplate reader. Columns, mean ( $\mathrm{n}=3$ ), bars, SE. (B) Cell viability of MDA-MB-23I cells treated with or without AuNPs and IR measured $24 \mathrm{~h}$ later after IR. The result of viability was quantified by counting the number of MDA-MB-23I cells. Columns, mean $(n=3)$, bars, $S E, * P<0.05$. (C) Viability of MDA-MB-23I cells treated with or without AuNPs and IR measured at 6 days after IR. Viability was determined using CCK-8. Columns, mean $(n=3)$, bars, $S E, * P<0.05$.

Abbreviations: RGD/P-AuNP, polyethylene-glycolylated gold nanoparticle (P-AuNP) conjugated with Arg-Gly-Asp (RGD) peptides; CCK-8, Cell Counting Kit-8; $\mathrm{SE}$, standard error; IR, ionizing radiation; ns, not significant.

damage and repair (Figure 5A). The number of residual $\gamma$-H2AX foci $12 \mathrm{~h}$ after IR was significantly high following combination treatment with RGD/P-AuNPs and 4 Gy IR compared to treatment with IR alone (Figure 5B). These data suggest that RGD/P-AuNPs can increase the effects of radiation on cancer cells by enhancing DNA damage.

\section{Inhibition of radiation-induced invasion by RGD/P-AuNPs in breast cancer cell lines}

Invasive recurrent disease after radiotherapy is a leading cause of mortality in breast cancer patients. We and others previously reported that cancer cell invasiveness may be increased by IR in a surviving population after IR treatment. ${ }^{16,17,39}$ Thus, we investigated the effect of RGD/ $\mathrm{P}$-AuNPs on breast cancer invasion after radiation treatment. To evaluate the effect of RGD/P-AuNPs and radiation on the invasive activity of breast cancer cells, we performed a Matrigel chemoinvasion assay. We found that invasion was increased in MDA-MB-231 or Hs578T cells $24 \mathrm{~h}$ after 4 Gy radiation treatment. Strikingly, cells treated with RGD/P-AuNPs and IR showed significantly decreased cell invasive activity compared to IR alone in MDA-MB-231 cells (Figure 6A) or Hs578T cells (Figure 6B) $\left(\mathrm{n}=3,{ }^{*} P<0.01\right)$. Treatment with RGD/P-AuNPs and IR did not affect cell morphology (Figure S4). These results suggest that RGD/ AuNPs suppress the radiation-induced invasive activity of breast cancer cells.

\section{Reduction of FN and extracellular signal- regulated kinase (ERK) signaling by combination treatment with RGD/ P-AuNPs and IR}

To understand the suppressive effects of RGD/P-AuNPs after IR on invasive activity, differential gene expression between the control group and RGD/P-AuNP-treated group was assessed by cDNA microarray. We found that FN expression was increased in the cells after 4 Gy IR, but this 

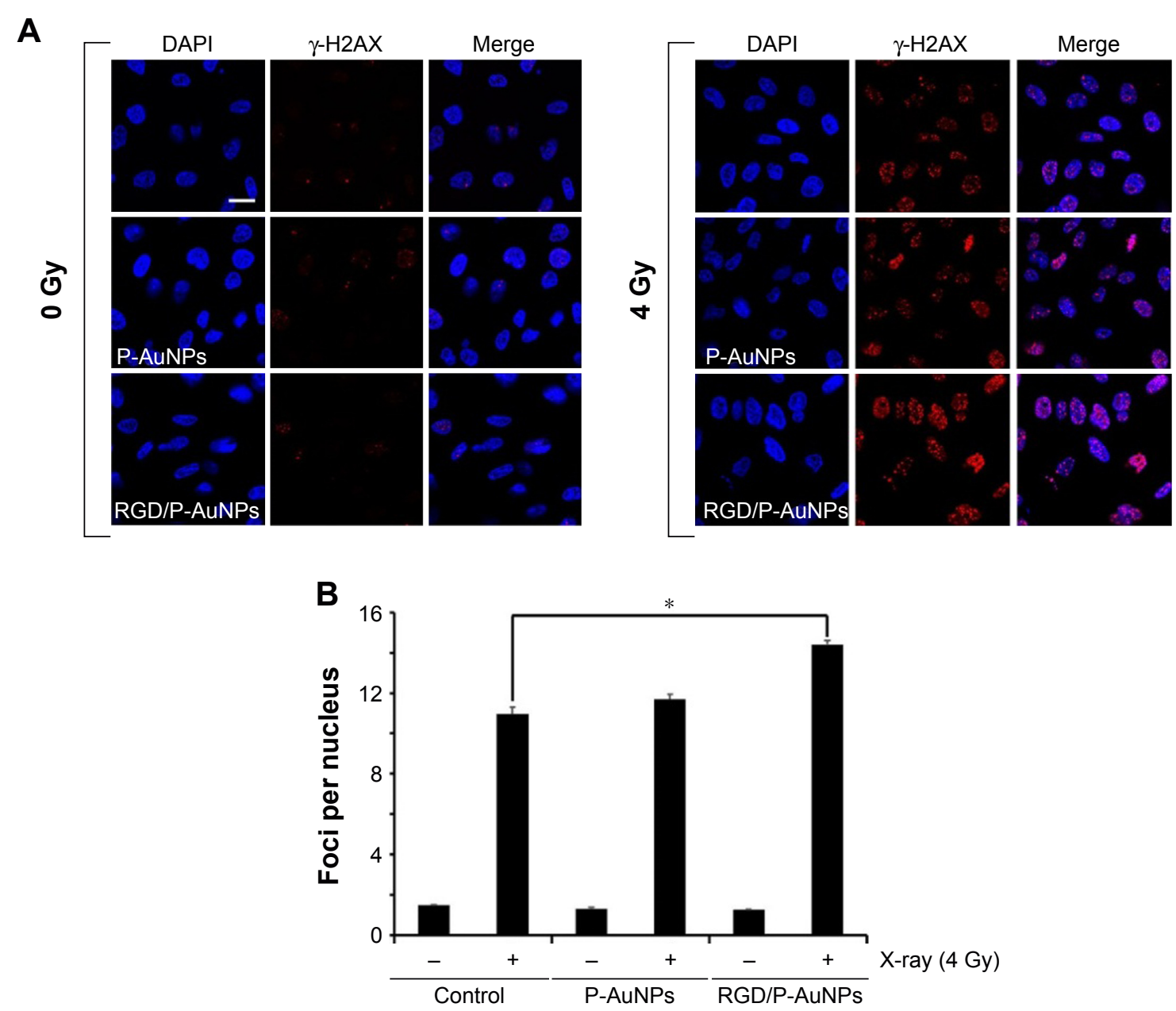

Figure 5 DNA damage after IR increased following treatment with RGD/P-AuNPs.

Notes: (A) Representative confocal immunofluorescence images of $\gamma$-H2AX (red) in MDA-MB-23I cells after treatment with AuNPs and radiation (0 Gy or 4 Gy). Bar, $20 \mu \mathrm{m}$. (B) Number of $\gamma-\mathrm{H} 2 \mathrm{AX}$ foci per nucleus in MDA-MB-23I cells was counted. Cells pre-cultured with AuNPs were fixed and stained with $\gamma$-H2AX antibody $12 \mathrm{~h}$ after IR (0 Gy or 4 Gy). At least 50 nuclei were counted in each independent experiment. Columns, mean $(n=3)$, bars, $S E, * P<0.05$.

Abbreviations: IR, ionizing radiation; RGD/P-AuNP, polyethylene-glycolylated gold nanoparticle (P-AuNP) conjugated with Arg-Gly-Asp (RGD) peptides; SE, standard error.
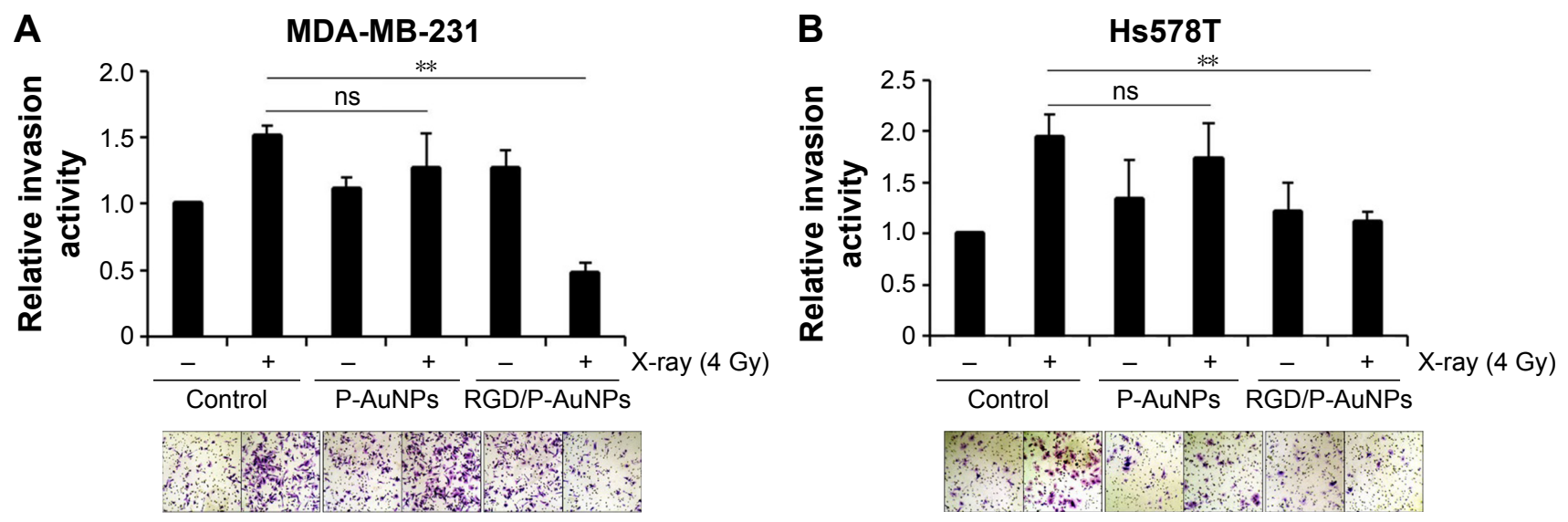

Figure 6 RGD/P-AuNPs inhibit IR-induced invasive activities of breast cancer cells

Notes: (A, B) Cells were pre-cultured with AuNPs for $48 \mathrm{~h}$, followed by IR treatment. Matrigel chemoinvasion activities were measured in (A) MDA-MB-23I cells and (B) Hs578T cells at $24 \mathrm{~h}$ after IR treatment. Columns, mean $(\mathrm{n}=3)$, bars, $\mathrm{SE}, * * P<0.01$.

Abbreviations: RGD/P-AuNP, polyethylene-glycolylated gold nanoparticle (P-AuNP) conjugated with Arg-Gly-Asp (RGD) peptides; IR, ionizing radiation; SE, standard error; ns, not significant. 
Table I Expression of invasion-related genes in MDA-MB-23 I cells

\begin{tabular}{|c|c|c|c|c|c|c|}
\hline \multirow{3}{*}{$\begin{array}{l}\text { Gene } \\
\text { symbol }\end{array}$} & \multirow[t]{3}{*}{ Gene name } & \multicolumn{4}{|c|}{ Global normalization } & \multirow{3}{*}{$\begin{array}{l}\text { Fold change } \\
\text { of control and } \\
\text { RGD/P-AuNPs } \\
\text { groups ( } 4 \mathrm{~Gy} \text { ) }\end{array}$} \\
\hline & & \multicolumn{2}{|c|}{ Control } & \multicolumn{2}{|c|}{ RGD/P-AuNPs } & \\
\hline & & 0 Gy & $4 \mathrm{~Gy}$ & $0 \mathrm{~Gy}$ & $4 \mathrm{~Gy}$ & \\
\hline FN I & Fibronectin precursor & 81 & 428 & 88 & 215 & $0.50 *$ \\
\hline COL6AI & Collagen alpha-I $(\mathrm{VI})$ chain precursor & 22 & 20 & 17 & 15 & 0.75 \\
\hline COLIA2 & Collagen alpha-2(VI) chain precursor & 6 & 5 & 4 & 4 & 0.80 \\
\hline C9orfI26 & Protein SCAI & 10 & 12 & 10 & 10 & 0.83 \\
\hline CD44 & CD44 antigen precursor & 262 & 269 & 281 & 245 & 0.91 \\
\hline CLDN7 & Claudin-7 & 287 & 296 & 252 & 272 & 0.92 \\
\hline CLDNI & Claudin-I & 22 & 23 & 22 & 22 & 0.96 \\
\hline MET & Hepatocyte growth factor receptor precursor (HGF receptor) & 140 & 146 & 106 & 141 & 0.97 \\
\hline ICAMI & Intercellular adhesion molecule I precursor & 105 & 89 & 83 & 87 & 0.98 \\
\hline BMP7 & Bone morphogenetic protein 7 precursor & 2 & 2 & 1 & 2 & 1.00 \\
\hline CADMI & Cell adhesion molecule I precursor & 2 & 2 & 1 & 2 & 1.00 \\
\hline COLIAI & Collagen alpha-I (I) chain precursor & 2 & 2 & I & 2 & 1.00 \\
\hline COL3AI & Collagen alpha-I (III) chain precursor & 2 & 2 & 2 & 2 & 1.00 \\
\hline MMP9 & Matrix metalloproteinase 9 precursor & 2 & 2 & 1 & 2 & 1.00 \\
\hline PCDHI & Protocadherin- 15 precursor & 2 & 2 & 2 & 2 & 1.00 \\
\hline $\mathrm{CDH} 3$ & Cadherin-3 precursor & 9 & 8 & 7 & 8 & 1.00 \\
\hline OCLN & Occludin & 32 & 34 & 32 & 37 & 1.09 \\
\hline VTN & Vitronectin precursor & 31 & 27 & 29 & 31 & 1.15 \\
\hline
\end{tabular}

Notes: *, > I.5-fold increasing (up) or $<0.67$-fold decreasing (down) expression from 4 Gy RGD/P-AuNPs group to control group. Fibronection precursor (bold) is the only one which showed $<0.67$-fold decreasing expression after RGD/P-AuNP and radiation treatment within invasion-related genes.

Abbreviation: RGD/P-AuNP, polyethylene-glycolylated gold nanoparticle (P-AuNP) conjugated with Arg-Gly-Asp (RGD) peptides.

increase was negated by RGD/P-AuNP treatment (Table 1). We confirmed that the messenger RNA (mRNA) level of total FN was downregulated by RGD/P-AuNP and IR treatments based on using quantitative real-time PCR (Figure 7A). As a possible molecular mechanism that functions downstream of FN and integrins, we evaluated the potential role of ERK, a downstream protein of integrins implicated in cell invasion. ${ }^{16}$ We hypothesized that downregulation of FN and ERK signaling may be involved in suppressing invasive activity after treatment with RGD/P-AuNPs and IR. Indeed, ERK phosphorylation was downregulated after IR treatment in the presence of RGD/P-AuNPs (Figure 7B). Taken together, these data suggest that the reduction of ERK signaling downstream of FN by RGD/P-AuNPs is involved in suppressing invasiveness post-IR, which may be a promising strategy for improving the efficacy of radiotherapy.

\section{Discussion}

In this study, we targeted integrins by conjugating RGD peptides on AuNPs to enhance radiation effect. RGD/P-AuNPs
A

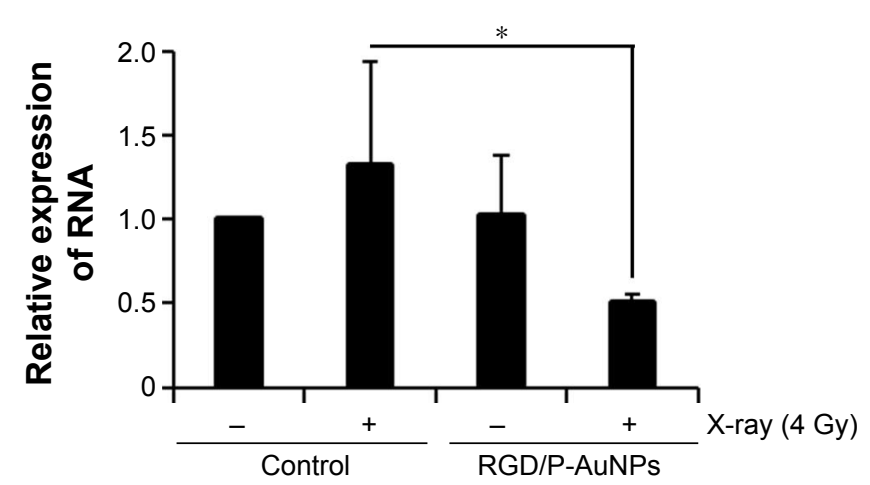

B

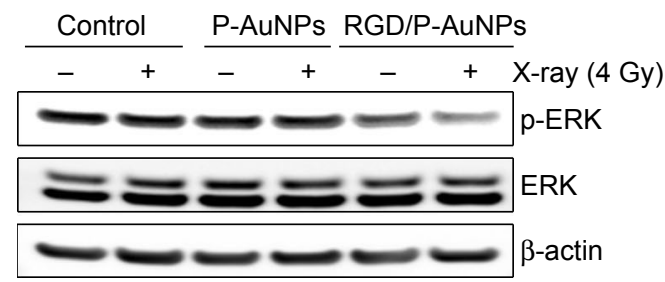

Figure 7 Expression of FN and phosphorylated ERK was downregulated after IR in combination with RGD/P-AuNPs in MDA-MB-23I cells.

Notes: (A) Quantification of mRNA levels of FN in MDA-MB-23I cells assessed by quantitative real-time PCR. The levels of FN are relative to I8S $r R N A$ ( $n=5$, $* P<0.05$ ). (B) Total cell lysates after AuNP and IR treatments were subjected to Western blot analysis using the indicated antibodies ( $\mathrm{n}=3$ ).

Abbreviations: FN, fibronectin; ERK, extracellular signal-regulated kinase; IR, ionizing radiation; RGD/P-AuNP, polyethylene-glycolylated gold nanoparticle (P-AuNP) conjugated with Arg-Gly-Asp (RGD) peptides; mRNA, messenger RNA. 
were efficiently internalized through $\alpha 5$ - and $\alpha$ v-integrins in invasive and integrin overexpressing breast cancer cells. Our results suggest that RGD/P-AuNPs, after internalization via endocytosis with integrins, accumulate at late endosomes and lysosomes by vesicle trafficking.

A previous study showed that AuNPs are mainly localized in the cytoplasm rather than in the nucleus of cells. ${ }^{34}$ To utilize AuNPs in cancer therapy, we and others have functionalized AuNPs with peptides; the functionalized AuNPs can localize in specific cell organelles. Mackey et al ${ }^{8,40}$ conjugated AuNPs with a nuclear localization sequence peptide to induce internalization of AuNPs into the nucleus. Chang et $\mathrm{al}^{41}$ reported that AuNPs localize in the endoplasmic reticulum (ER) and Golgi apparatus in murine melanoma cells. They hypothesized that continuous ER stress induced by accumulation of AuNPs results in apoptotic cell death. In contrast, other studies have revealed that AuNPs accumulated in endosomes or lysosomes. ${ }^{4,42-45}$

Ma et $\mathrm{al}^{42}$ showed that AuNPs accumulate in the lysosomes in a size-dependent manner and impair the degradation capacity of lysosomes related to autophagy. Our results indicate that surface modification of P-AuNPs with RGD peptide plays an important role in efficient cellular internalization by the endocytotic pathway through integrins and accumulation in late endosomes and lysosomes. Further studies are needed to understand the effects of radiation and accumulation of RGD/P-AuNPs on the function of endosomes or lysosomes.

In a previous study, large AuNPs of $15 \mathrm{~nm}$ in diameter did not show cytotoxicity in several cell lines. ${ }^{46}$ AuNPs show nearly no or very low cytotoxicity in cells and better biocompatibility compared to other high atomic number $(Z)$ materials. ${ }^{47,48}$ Similarly, our data indicate that AuNPs alone are not cytotoxic to cells. However, DNA damage increased and cell viability decreased following radiation treatment in the presence of RGD/P-AuNPs in MDA-MB-231 cells.

To further examine the mechanism of increasing radiosensitivity using AuNPs, several methods have been considered, including measuring DNA damage by $\gamma-\mathrm{H} 2 \mathrm{AX}$ foci detection, apoptosis detection or ROS measurement. Radiation induces cancer cell damage by ionizing water to form free radicals and causes double-strand DNA breaks. Zheng et $\mathrm{al}^{49}$ treated plasmid DNA with $60 \mathrm{keV}$ electrons alone or in the presence of AuNPs. The AuNPs increased the number of DNA double-strand breaks by $\sim 2.5$-fold in their study. To evaluate DNA damage, we and others used immunofluorescence study of $\gamma-\mathrm{H} 2 \mathrm{AX}$. Mirjolet et $\mathrm{al}^{50}$ used titanate nanotubes (TiONts) to treat the SNB-19 and U87MG cell lines with 2 Gy IR. The percentage of cells with high
$\gamma$-H2AX foci ( $>8$ per nucleus) increased in the TiONts and IR group compared to IR alone in SNB-19 human glioma cell line. Joh et $\mathrm{al}^{51}$ used PEGylated AuNPs to treat the human U251 glioblastoma cell line with 4 Gy IR. A custom macro in Image J software was used to quantify $\gamma$-H2AX density. AuNPs with IR led to a 1.7 -fold increase in $\gamma$-H2AX density in U251 cells compared with the IR-alone group. Although previous studies have reported that nano materials enhance DNA damage by radiation treatment, Gilles et $\mathrm{al}^{12}$ showed that AuNPs functionalization can affect hydroxyl radical production, which is correlated to DNA damage. Their results showed that functionalized AuNPs decreases hydroxyl radical productions and lower DNA damage compared to nonfunctionalized AuNPs. Taking the results, they suggested that functionalization of AuNPs should be designed to keep the most efficient for radiotherapy application. Our results show that the RGD peptide-conjugated AuNPs increase DNA damage after radiation, which means that RGD/ $\mathrm{P}$-AuNPs do not reduce hydroxyl radical production and may not decrease the DNA damage after IR. In fact, compared to the IR-alone group, the average number of $\gamma$-H2AX foci per nucleus measured $12 \mathrm{~h}$ later increased in the combination group of RGD/P-AuNP and 4 Gy IR treatments. Importantly, the mechanism that increased the radiosensitivity of AuNPs may be attributed not only to DNA damage but also to the relationship between apoptosis induction, ROS production and mitochondrial alternation. ${ }^{10,41,52}$

Several different methods can be used to evaluate radiosensitivity in the presence of AuNPs. Some studies used clonogenic assays and multiple doses to construct a survival curve, ${ }^{41,53-56}$ while others conducted viable cell counting, metabolic assays (enzymatic reduction of tetrazolium dye including MTT, MTS or WST-1) and resazurin sodium salt reduction (Alamar blue test) at a single radiation dose. ${ }^{57-59}$ Thus, it is difficult to compare our results for radiosensitivity with those of other studies because different cell lines, AuNPs, radiation energy, radiation dosage, evaluation methods and measurement time of cell viability after IR were used. In our study, the viability of MDA-MB-231 cells treated with RGD/P-AuNPs and 4 Gy IR decreased by $~ 17 \%$ according to cell counting assay results and decreased by $\sim 16 \%$ based on CCK- 8 metabolic assays compared to IR alone. Compared to other single-dose studies, Roa et $\mathrm{al}^{53}$ used glucose-capped AuNPs to treat the prostate cancer cell line DU-145 with 2 Gy IR. The cell viability of DU-145 cells decreased, with a $26.8 \%$ inhibition rate measured by MTT assay. Coulter et al used $1.9 \mathrm{~nm}$ AuNPs to treat different cancer cell lines with 3 Gy IR. A significant cytotoxic effect of AuNPs was observed in MDA-MB-231 cells in a 
clonogenic assay, showing a $21 \%$ reduction in the surviving fraction; however, no reduction was observed in DU145 or L132 cells. ${ }^{60}$ Xiao et al evaluated the viability of HeLa cells after exposure to multifunctional core/satellite nanotheranostics followed by 6 Gy IR. Cell viability decreased by $\sim 21 \%$ following treatment with nanotheranostics compared to IR alone. ${ }^{61}$ According to these in vitro studies, cell viability after combination of AuNP and IR treatments was decreased by $\sim 20 \%$. Our data of cell viability are similar with previous recent studies, although it is difficult to compare our results with other studies because of different experimental conditions and evaluation methods.

In this study, we determined not only sensitizing effect but also the suppressive effect on the invasive activity by $\mathrm{RGD} / \mathrm{P}-\mathrm{AuNPs}$ in cancer cells after radiation. Invasiveness is the most important factor used to distinguish benign from malignant lesions and is also an important pathological feature related to prognosis. ${ }^{62}$ Lymphovascular invasion is an independent predictor of poor prognosis in breast cancer patients. ${ }^{63,64}$ Highly invasive cancer can escape local treatment and cause recurrence. A previous study suggested a mechanism for tumor recurrence post-IR, in which radiation attracts circulating cancer cells to the site of treatment. ${ }^{65}$ Despite advances in cancer therapy, recurrence is nearly inevitable in the presence of an aggressively spreading cancer. ${ }^{66}$ Our findings indicate that AuNPs can be used as a novel therapy to suppress the invasive activity of cancer cells after radiotherapy.

The invasion of cancer cells is related to the regulation of several molecular factors, including cell adhesion molecules such as integrins, cadherins, desmosomes, selectins, CD44 and epithelial-mesenchymal transition (EMT)-related factors such as matrix metalloproteinases (MMPs), bone morphogenetic protein (BMP7) and epithelial protein lost in neoplasm (EPLIN). ${ }^{67}$ Binding of integrins to their ligands, such as FN, activates focal adhesion kinase (FAK), which further activates multiple signaling proteins. The phosphorylated FAK binds to growth factor receptor-bound protein 2 (GRB2) and activates the small GTPase Ras. Activated Ras recruits Raf, leading to mitogen-activated protein kinase (MEK) and ERK activation. ${ }^{68}$ Several studies suggested that targets downstream of ERK play key roles in angiogenesis, cell migration, invasion and metastasis. ${ }^{69,70}$

In our study, the expression of FN mRNA was suppressed by combination treatment with RGD/P-AuNPs and IR, which may lead to a decrease in FN. Liu et $\mathrm{al}^{71}$ used AuNPs to treat lung cancer cells and investigated the cytotoxicity and the effect on the invasive activity of cells. Their study showed that invasive activity increased after AuNP treatment, and the mechanism may be associated with the increase of MMP9 and intercellular adhesion molecule 1 (ICAM1) expression. Based on our microarray analysis results, however, the expression of MMP9, ICAM1 and other invasion-related molecules did not clearly change. Further studies are needed to determine the detailed molecular mechanisms.

\section{Conclusion}

We targeted integrins by conjugating RGD peptides on to AuNPs to achieve enhanced radiation effects. RGD/P-AuNPs were internalized efficiently through $\alpha 5$ - and $\alpha v$-integrins in invasive and integrin-overexpressing breast cancer cells. RGD/P-AuNPs colocalized with integrins and accumulated in late endosomes and lysosomes. Furthermore, RGD/PAuNPs suppressed the invasive activity of breast cancer cells associated with IR treatment. The expression of FN and activation of ERK, key modulators of cancer cell invasion, were suppressed by RGD/P-AuNPs in combination with IR. Taken together, our results suggest that RGD/P-AuNPs are a useful therapeutic agent for suppressing invasiveness after IR by targeting FN-integrin signaling, which may be a promising strategy for improving the efficacy of radiotherapy.

\section{Acknowledgments}

We thank Dr Chi-Che Hsieh, Noriko Sasaki and Keiko Kanno for technical assistant. We also thank Midori Tokuda and Mari Horikawa for administrative work. We are grateful to Alexandra M Meilhac for her critical reading of the manuscript. This work was supported in part by the GI-CoRE in Hokkaido University and by the Grant-in Aid from Scientific Research (C) to JN (16K10380).

\section{Disclosure}

JMN, HS and TH disclose financial interest in Aisin Seiki Co., Ltd and IMRA America, Inc. The other authors report no conflicts of interest in this work.

\section{References}

1. Qin M, Lee YE, Ray A, Kopelman R. Overcoming cancer multidrug resistance by codelivery of doxorubicin and verapamil with hydrogel nanoparticles. Macromol Biosci. 2014;14(8):1106-1115.

2. Allijn IE, Leong W, Tang J, et al. Gold nanocrystal labeling allows lowdensity lipoprotein imaging from the subcellular to macroscopic level. ACS Nano. 2013;7(11):9761-9770.

3. Cuenca AG, Jiang H, Hochwald SN, Delano M, Cance WG, Grobmyer SR. Emerging implications of nanotechnology on cancer diagnostics and therapeutics. Cancer. 2006;107(3):459-466.

4. Naha PC, Lau KC, Hsu JC, et al. Gold silver alloy nanoparticles (GSAN): an imaging probe for breast cancer screening with dual-energy mammography or computed tomography. Nanoscale. 2016;8(28): 13740-13754. 
5. Kwatra D, Venugopal A, Anant S. Nanoparticles in radiation therapy: a summary of various approaches to enhance radiosensitization in cancer. Trans Cancer Res. 2013;2(4):330-342.

6. Qin M, Zong H, Kopelman R. Click conjugation of peptide to hydrogel nanoparticles for tumor-targeted drug delivery. Biomacromolecules. 2014;15(10):3728-3734.

7. Ali MR, Panikkanvalappil SR, El-Sayed MA. Enhancing the efficiency of gold nanoparticles treatment of cancer by increasing their rate of endocytosis and cell accumulation using rifampicin. J Am Chem Soc. 2014;136(12):4464-4467.

8. Mackey MA, El-Sayed MA. Chemosensitization of cancer cells via gold nanoparticle-induced cell cycle regulation. Photochem Photobiol. 2014;90(2):306-312.

9. Perrault SD, Walkey C, Jennings T, Fischer HC, Chan WC. Mediating tumor targeting efficiency of nanoparticles through design. Nano Lett. 2009;9(5):1909-1915.

10. Misawa M, Takahashi J. Generation of reactive oxygen species induced by gold nanoparticles under x-ray and UV Irradiations. Nanomedicine. 2011;7(5):604-614.

11. Chattopadhyay N, Cai Z, Kwon YL, Lechtman E, Pignol JP, Reilly RM. Molecularly targeted gold nanoparticles enhance the radiation response of breast cancer cells and tumor xenografts to X-radiation. Breast Cancer Res Treat. 2013;137(1):81-91.

12. Gilles M, Brun E, Sicard-Roselli C. Gold nanoparticles functionalization notably decreases radiosensitization through hydroxyl radical production under ionizing radiation. Colloids Surf B Biointerfaces. 2014;123:770-777.

13. Early Breast Cancer Trialists' Collaborative Group (EBCTCG); Darby S, McGale P, et al. Effect of radiotherapy after breast-conserving surgery on 10-year recurrence and 15-year breast cancer death: metaanalysis of individual patient data for 10,801 women in 17 randomised trials. Lancet. 2011;378(9804):1707-1716.

14. Darby SC, Ewertz M, McGale P, et al. Risk of ischemic heart disease in women after radiotherapy for breast cancer. $N$ Engl J Med. 2013; 368(11):987-998.

15. Hayes SB, Freedman GM, Li T, Anderson PR, Ross E. Does axillary boost increase lymphedema compared with supraclavicular radiation alone after breast conservation? Int J Radiat Oncol Biol Phys. 2008; 72(5):1449-1455.

16. Qian LW, Mizumoto K, Urashima T, et al. Radiation-induced increase in invasive potential of human pancreatic cancer cells and its blockade by a matrix metalloproteinase inhibitor, CGS27023. Clin Cancer Res. 2002;8(4):1223-1227.

17. Nam JM, Ahmed KM, Costes S, et al. beta1-Integrin via NF-kappaB signaling is essential for acquisition of invasiveness in a model of radiation treated in situ breast cancer. Breast Cancer Res. 2013; 15(4):R60

18. Hynes RO. Integrins: bidirectional, allosteric signaling machines. Cell. 2002;110(6):673-687.

19. Desgrosellier JS, Cheresh DA. Integrins in cancer: biological implications and therapeutic opportunities. Nat Rev Cancer. 2010;10(1):9-22.

20. Nam JM, Chung Y, Hsu HC, Park CC. Betal integrin targeting to enhance radiation therapy. Int J Radiat Biol. 2009;85(11):923-928.

21. Makrilia N, Kollias A, Manolopoulos L, Syrigos K. Cell adhesion molecules: role and clinical significance in cancer. Cancer Invest. 2009; 27(10):1023-1037.

22. Rainero E, Norman JC. Late endosomal and lysosomal trafficking during integrin-mediated cell migration and invasion: cell matrix receptors are trafficked through the late endosomal pathway in a way that dictates how cells migrate. Bioessays. 2013;35(6):523-532.

23. Dozynkiewicz MA, Jamieson NB, Macpherson I, et al. Rab25 and CLIC3 collaborate to promote integrin recycling from late endosomes/lysosomes and drive cancer progression. Dev Cell. 2012;22(1): $131-145$.

24. Lobert VH, Brech A, Pedersen NM, et al. Ubiquitination of alpha 5 beta 1 integrin controls fibroblast migration through lysosomal degradation of fibronectin-integrin complexes. Dev Cell. 2010;19(1):148-159.
25. Onodera Y, Nam JM, Hashimoto A, et al. Rab5c promotes AMAP1PRKD2 complex formation to enhance beta1 integrin recycling in EGF-induced cancer invasion. J Cell Biol. 2012;197(7):983-996.

26. Qian W, Murakami M, Ichikawa Y, Che Y. Highly efficient and controllable PEGylation of gold nanoparticles prepared by femtosecond laser ablation in water. J Phys Chem C. 2011;115(47):23293-23298.

27. Shao X, Schnau P, Qian W, Wang X. Quantitatively understanding cellular uptake of gold nanoparticles via radioactivity analysis. J Nanosci Nanotechnol. 2015;15(5):3834-3838.

28. Chen H, Paholak H, Ito M, et al. 'Living' PEGylation on gold nanoparticles to optimize cancer cell uptake by controlling targeting ligand and charge densities. Nanotechnology. 2013;24(35):355101.

29. Schneider CA, Rasband WS, Eliceiri KW. NIH Image to ImageJ: 25 years of image analysis. Nat Methods. 2012;9(7):671-675.

30. Onodera Y, Hashimoto S, Hashimoto A, et al. Expression of AMAP1, an ArfGAP, provides novel targets to inhibit breast cancer invasive activities. EMBO J. 2005;24(5):963-973.

31. Nam JM, Onodera Y, Mazaki Y, Miyoshi H, Hashimoto S, Sabe H CIN85, a Cbl-interacting protein, is a component of AMAP1-mediated breast cancer invasion machinery. EMBO J. 2007;26(3):647-656.

32. Pankov R, Yamada KM. Fibronectin at a glance. J Cell Sci. 2002; 115(pt 20):3861-3863.

33. Nam JM, Onodera Y, Bissell MJ, Park CC. Breast cancer cells in three-dimensional culture display an enhanced radioresponse after coordinate targeting of integrin alpha5beta1 and fibronectin. Cancer Res. 2010;70(13):5238-5248.

34. Chithrani DB, Jelveh $\mathrm{S}$, Jalali F, et al. Gold nanoparticles as radiation sensitizers in cancer therapy. Radiat Res. 2010;173(6):719-728.

35. Christoforidis S, McBride HM, Burgoyne RD, Zerial M. The Rab5 effector EEA1 is a core component of endosome docking. Nature. 1999;397(6720):621-625.

36. Zerial M, McBride H. Rab proteins as membrane organizers. Nat Rev Mol Cell Biol. 2001;2(2):107-117.

37. Feng Y, Press B, Wandinger-Ness A. Rab 7: an important regulator of late endocytic membrane traffic. J Cell Biol. 1995;131(6 pt 1): 1435-1452.

38. Lombardi D, Soldati T, Riederer MA, Goda Y, Zerial M, Pfeffer SR. Rab9 functions in transport between late endosomes and the trans Golgi network. EMBO J. 1993;12(2):677-682.

39. Paquette B, Therriault H, Desmarais G, Wagner R, Royer R, Bujold R. Radiation-enhancement of MDA-MB-231 breast cancer cell invasion prevented by a cyclooxygenase-2 inhibitor. Br J Cancer. 2011; 105(4):534-541.

40. Mackey MA, Saira F, Mahmoud MA, El-Sayed MA. Inducing cancer cell death by targeting its nucleus: solid gold nanospheres versus hollow gold nanocages. Bioconjug Chem. 2013;24(6):897-906.

41. Chang MY, Shiau AL, Chen YH, Chang CJ, Chen HH, Wu CL. Increased apoptotic potential and dose-enhancing effect of gold nanoparticles in combination with single-dose clinical electron beams on tumor-bearing mice. Cancer Sci. 2008;99(7):1479-1484.

42. Ma X, Wu Y, Jin S, et al. Gold nanoparticles induce autophagosome accumulation through size-dependent nanoparticle uptake and lysosome impairment. ACS Nano. 2011;5(11):8629-8639.

43. Yang PH, Sun X, Chiu JF, Sun H, He QY. Transferrin-mediated gold nanoparticle cellular uptake. Bioconjug Chem. 2005;16(3):494-496.

44. Soman N, Marsh J, Lanza G, Wickline S. New mechanisms for non-porative ultrasound stimulation of cargo delivery to cell cytosol with targeted perfluorocarbon nanoparticles. Nanotechnology. 2008; 19(18): 185102.

45. Chithrani BD, Stewart J, Allen C, Jaffray DA. Intracellular uptake, transport, and processing of nanostructures in cancer cells. Nanomedicine. 2009;5(2):118-127.

46. Pan Y, Neuss S, Leifert A, et al. Size-dependent cytotoxicity of gold nanoparticles. Small. 2007;3(11):1941-1949.

47. Connor EE, Mwamuka J, Gole A, Murphy CJ, Wyatt MD. Gold nanoparticles are taken up by human cells but do not cause acute cytotoxicity. Small. 2005;1(3):325-327. 
48. Shukla R, Bansal V, Chaudhary M, Basu A, Bhonde RR, Sastry M. Biocompatibility of gold nanoparticles and their endocytotic fate inside the cellular compartment: a microscopic overview. Langmuir. 2005;21(23):10644-10654.

49. Zheng Y, Hunting DJ, Ayotte P, Sanche L. Radiosensitization of DNA by gold nanoparticles irradiated with high-energy electrons. Radiat Res. 2008;169(1):19-27.

50. Mirjolet $\mathrm{C}$, Papa AL, Crehange G, et al. The radiosensitization effect of titanate nanotubes as a new tool in radiation therapy for glioblastoma: a proof-of-concept. Radiother Oncol. 2013;108(1):136-142.

51. Joh DY, Sun L, Stangl M, et al. Selective targeting of brain tumors with gold nanoparticle-induced radiosensitization. PLoS One. 2013; 8(4):e62425

52. Taggart LE, McMahon SJ, Currell FJ, Prise KM, Butterworth KT. The role of mitochondrial function in gold nanoparticle mediated radiosensitisation. Cancer Nanotechnol. 2014;5(1):5.

53. Roa W, Zhang X, Guo L, et al. Gold nanoparticle sensitize radiotherapy of prostate cancer cells by regulation of the cell cycle. Nanotechnology. 2009;20(37):375101.

54. Liu CJ, Wang $\mathrm{CH}$, Chen $\mathrm{ST}$, et al. Enhancement of cell radiation sensitivity by pegylated gold nanoparticles. Phys Med Biol. 2010; 55(4):931-945.

55. Butterworth KT, McMahon SJ, Currell FJ, Prise KM. Physical basis and biological mechanisms of gold nanoparticle radiosensitization. Nanoscale. 2012;4(16):4830-4838.

56. Rima W, Sancey L, Aloy MT, et al. Internalization pathways into cancer cells of gadolinium-based radiosensitizing nanoparticles. Biomaterials. 2013;34(1):181-195.

57. Xiao L, Zhang Y, Wang Y, et al. A polarized infrared thermal detector made from super-aligned multiwalled carbon nanotube films. Nanotechnology. 2011;22(2):025502.

58. Kong T, Zeng J, Wang X, et al. Enhancement of radiation cytotoxicity in breast-cancer cells by localized attachment of gold nanoparticles. Small. 2008;4(9):1537-1543.

59. Khoshgard K, Hashemi B, Arbabi A, Rasaee MJ, Soleimani M. Radiosensitization effect of folate-conjugated gold nanoparticles on HeLa cancer cells under orthovoltage superficial radiotherapy techniques. Phys Med Biol. 2014;59(9):2249-2263.
60. Coulter JA, Jain S, Butterworth KT, et al. Cell type-dependent uptake, localization, and cytotoxicity of $1.9 \mathrm{~nm}$ gold nanoparticles. Int $J$ Nanomedicine. 2012;7:2673-2685.

61. Xiao Q, Zheng X, Bu W, et al. A core/satellite multifunctional nanotheranostic for in vivo imaging and tumor eradication by radiation/ photothermal synergistic therapy. J Am Chem Soc. 2013;135(35): 13041-13048

62. Eccles SA, Box C, Court W. Cell migration/invasion assays and their application in cancer drug discovery. Biotechnol Annu Rev. 2005;11: $391-421$.

63. Soerjomataram I, Louwman MW, Ribot JG, Roukema JA, Coebergh JW. An overview of prognostic factors for long-term survivors of breast cancer. Breast Cancer Res Treat. 2008;107(3):309-330.

64. Song YJ, Shin SH, Cho JS, Park MH, Yoon JH, Jegal YJ. The role of lymphovascular invasion as a prognostic factor in patients with lymph node-positive operable invasive breast cancer. J Breast Cancer. 2011; 14(3):198-203.

65. Vilalta M, Rafat M, Giaccia AJ, Graves EE. Recruitment of circulating breast cancer cells is stimulated by radiotherapy. Cell Rep. 2014;8(2): 402-409.

66. Molina JR, Yang P, Cassivi SD, Schild SE, Adjei AA. Non-small cell lung cancer: epidemiology, risk factors, treatment, and survivorship. Mayo Clin Proc. 2008;83(5):584-594.

67. Martin TA, Ye L, Sanders AJ, Lane J, Jiang WG. Cancer invasion and metastasis: molecular and cellular perspective. In: Jandial R, editor. Metastatic Cancer Clinical and Biological Perspectives. Austin, TX: Landes Bioscience; 2013:135-168.

68. Hood JD, Cheresh DA. Role of integrins in cell invasion and migration. Nat Rev Cancer. 2002;2(2):91-100.

69. Reddy KB, Nabha SM, Atanaskova N. Role of MAP kinase in tumor progression and invasion. Cancer Metastasis Rev. 2003;22(4):395-403.

70. Giehl K. Oncogenic Ras in tumour progression and metastasis. Biol Chem. 2005;386(3):193-205.

71. Liu Z, Wu Y, Guo Z, et al. Effects of internalized gold nanoparticles with respect to cytotoxicity and invasion activity in lung cancer cells. PLoS One. 2014;9(6):e99175. 


\section{Supplementary materials}

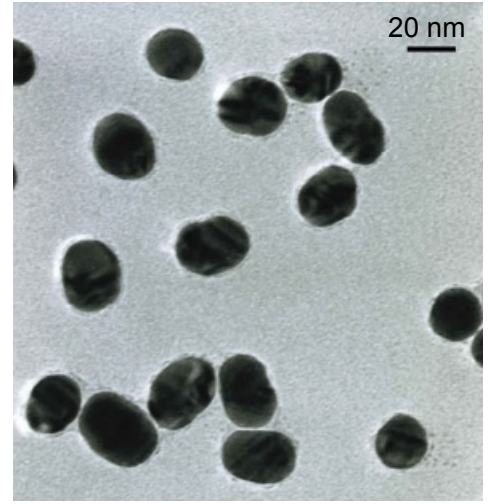

P-AuNPs

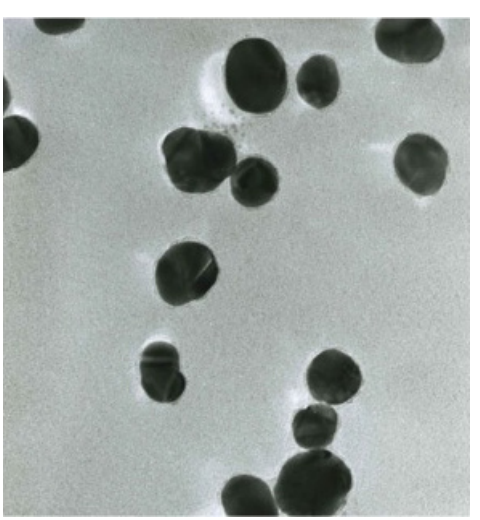

RGD/P-AuNPs

Figure SI TEM images of synthesized P-AuNPs and RGD/P-AuNPs.

Abbreviations: TEM, transmission electron microscope; RGD/P-AuNP, polyethylene-glycolylated gold nanoparticle (P-AuNP) conjugated with Arg-Gly-Asp (RGD) peptides.

A

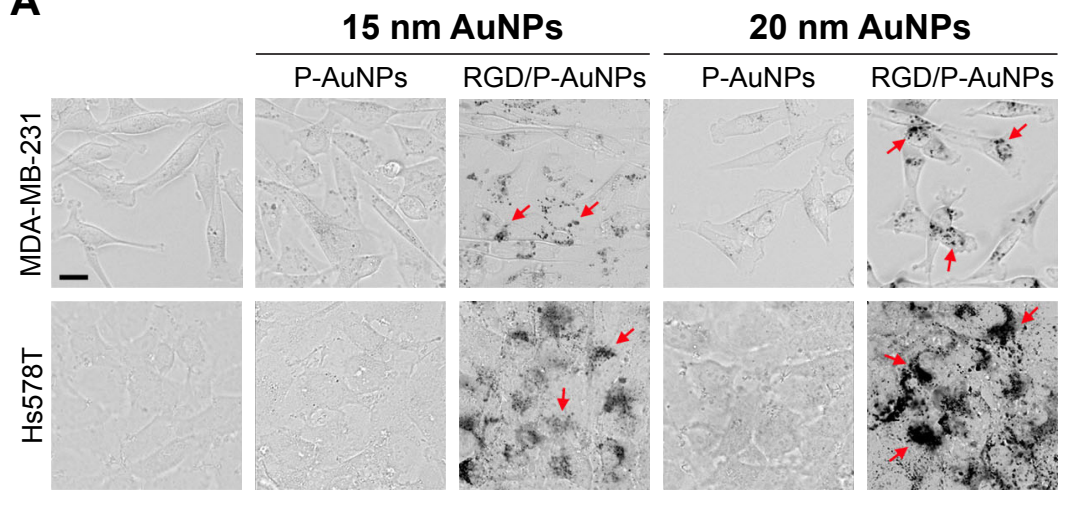

B

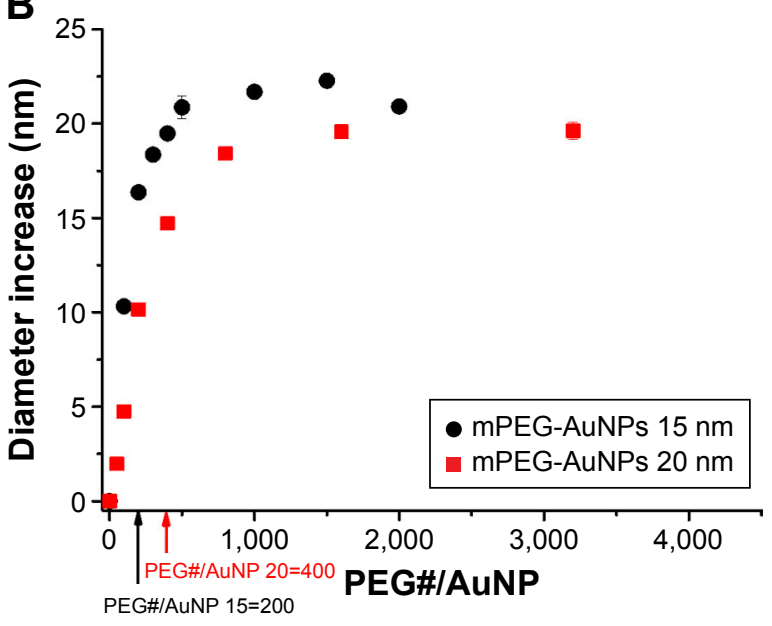

Figure S2 Characterization and internalization of AuNPs with diameters of $15 \mathrm{~nm}$ and $20 \mathrm{~nm}$.

Notes: (A) Phase-contrast microscopic images of different-sized AuNPs in MDA-MB-23I and Hs578T cells. Red arrow: localization of RGD/P-AuNPs. Bar, 20 $\mu$ m. (B) The hydrodynamic diameter of AuNPs was measured by DLS. Black arrow: saturation of RGD peptides on the surface of $15 \mathrm{~nm}$ sized P-AuNPs; red arrow: saturation of RGD peptides on the surface of $20 \mathrm{~nm}$ sized P-AuNPs.

Abbreviations: AuNP, gold nanoparticle; RGD/P-AuNP, polyethylene-glycolylated gold nanoparticle (P-AuNP) conjugated with Arg-Gly-Asp (RGD) peptides; DLS, dynamic light scattering; PEG, polyethylene glycolylated. 


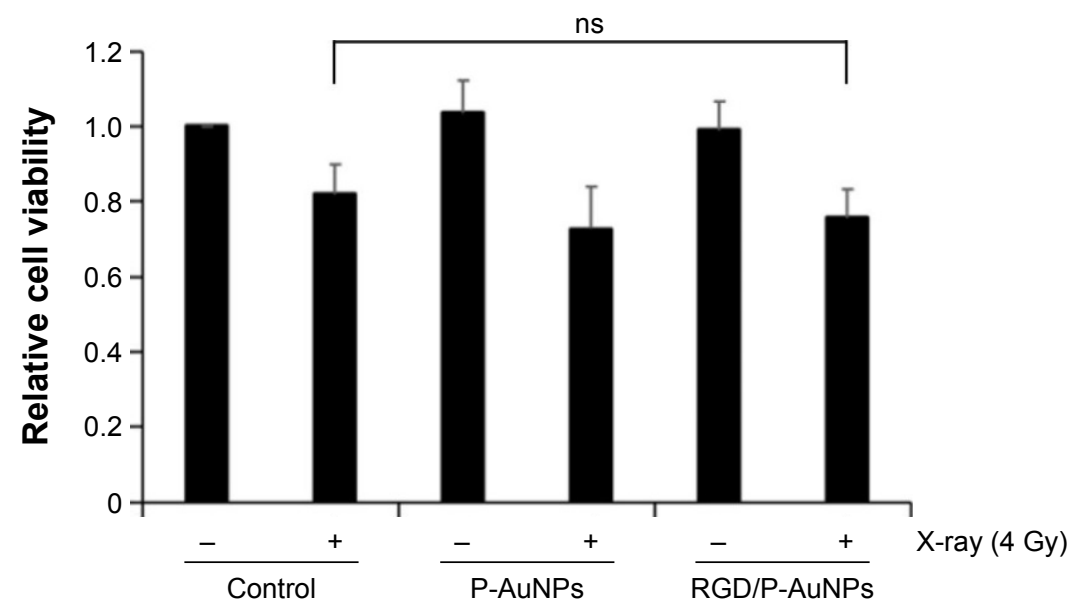

Figure S3 Radiosensitivity of SK-BR-3 cells treated with RGD/P-AuNPs.

Notes: Cell viability was quantified by counting of SK-BR-3 cells pre-cultured with AuNPs before radiation treatment. Columns, mean ( $n=3$ ), bars, SE.

Abbreviations: RGD/P-AuNP, polyethylene-glycolylated gold nanoparticle (P-AuNP) conjugated with Arg-Gly-Asp (RGD) peptides; SE, standard error; ns, not significant.

\section{A Control}
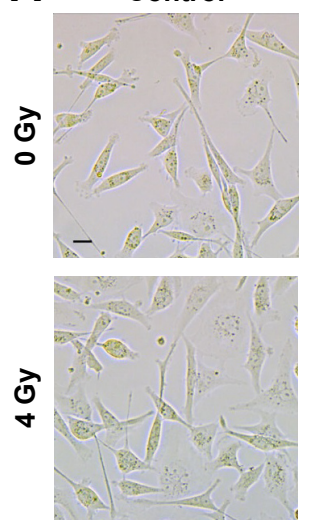

P-AuNPs
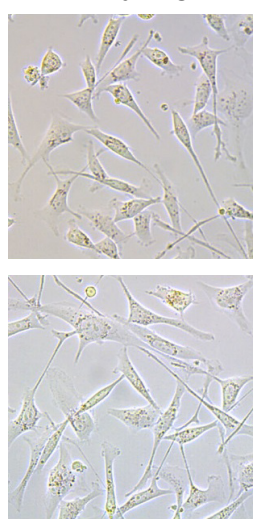

RGD/P-AuNPs
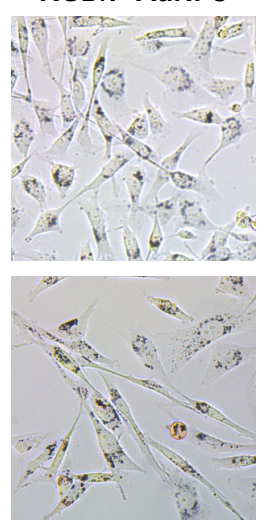

B

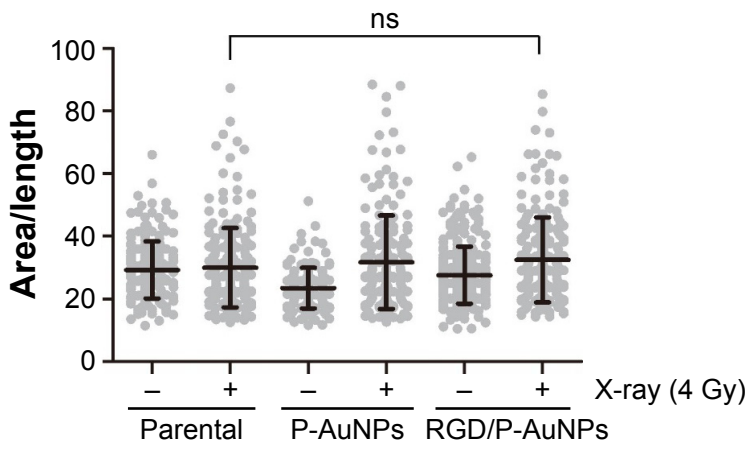

Figure S4 Assessment of morphological changes.

Notes: (A) Represent phase-contrast microscopic images of MDA-MB-23I cells treated with or without AuNPs and IR. Bar, $20 \mu \mathrm{m}$. (B) Column graph with scatter plot of area/length ratio. More than 150 cells were counted in each sample. Columns, mean, bars, SD.

Abbreviations: RGD/P-AuNP, polyethylene-glycolylated gold nanoparticle (P-AuNP) conjugated with Arg-Gly-Asp (RGD) peptides; SD, standard deviation; ns, not significant; IR, ionizing radiation. 
Video abstract

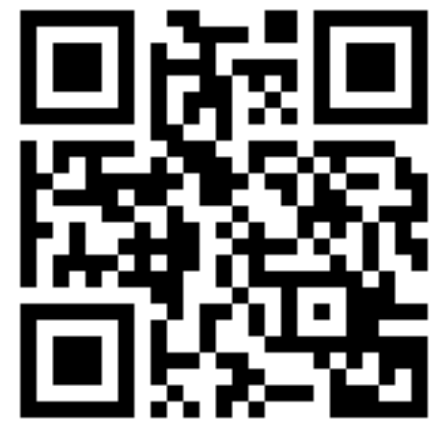

Point your SmartPhone at the code above. If you have a QR code reader the video abstract will appear. Or use:

http://youtu.be/ceT4f4xANhA

International Journal of Nanomedicine

\section{Publish your work in this journal}

The International Journal of Nanomedicine is an international, peerreviewed journal focusing on the application of nanotechnology in diagnostics, therapeutics, and drug delivery systems throughou the biomedical field. This journal is indexed on PubMed Central, MedLine, CAS, SciSearch ${ }^{\circledR}$, Current Contents ${ }^{\circledR} /$ Clinical Medicine,
Journal Citation Reports/Science Edition, EMBase, Scopus and the Elsevier Bibliographic databases. The manuscript management system is completely online and includes a very quick and fair peer-review system, which is all easy to use. Visit http://www.dovepress.com/ testimonials.php to read real quotes from published authors. 